\title{
Biodiversity in intensive and extensive grasslands in Finland: the impacts of spatial and temporal changes of agricultural land use
}

\author{
Juha Tiainen ${ }^{1,2}$, Terho Hyvönen ${ }^{3}$, Marleena Hagner ${ }^{3,4}$, Erja Huusela-Veistola ${ }^{3}$, Pauliina Louhi ${ }^{5}$, Antti Miettinen ${ }^{6}$, Tiina M. \\ Nieminen ${ }^{1}$, Ansa Palojärvi ${ }^{7}$, Tuomas Seimola ${ }^{1}$, Pauliina Taimisto ${ }^{8}$ and Perttu Virkajärvi ${ }^{8}$ \\ ${ }^{1}$ Natural Resources Institute Finland, PL 2, FI-00791 Helsinki, Finland \\ ${ }^{2}$ Lammi Biological Station, University of Helsinki, Fl-16900 Lammi, Finland \\ ${ }^{3}$ Natural Resources Institute Finland, Tietotie 4, Fl-31600 Jokioinen, Finland \\ ${ }^{4}$ Faculty of Biological and Environmental Sciences, Ecosystem and Environment Research Programme, \\ University of Helsinki, Fl-15140 Lahti, Finland \\ ${ }^{5}$ Natural Resources Institute Finland, Paavo Havaksentie 3, Fl-90570 Oulu, Finland \\ ${ }^{6}$ Natural Resources Institute Finland, Yliopistokatu 6 B, FI-80100 Joensuu, Finland \\ ${ }^{7}$ Natural Resources Institute Finland, Itäinen Pitkäkatu 4 A, FI-20520 Turku \\ ${ }^{8}$ Natural Resources Institute Finland, Halolantie 31 A, FI-71750 Maaninka, Finland \\ e-mail: juha.tiainen@luke.fi and juha.tiainen@helsinki.fi
}

\begin{abstract}
Biodiversity degradation is a national and global problem which is interconnected with land use and climate change. All these are major unsolved questions and their interactions are only partly understood. Agriculture and especially cattle farming is under keen societal focus because of its significant role in soil carbon losses, greenhouse gas (GHG) emissions and biodiversity preservation. We reviewed the Finnish scientific literature to assess the impact of intensive contra extensive grass production on biodiversity using vascular plants, vertebrates, invertebrates and soil biota. Still a few decades ago, mixed farming was prevailing almost everywhere in Finland, but nowadays cereal production is essentially clustered in the southwest and milk and beef production in the northeast. This is reflected in the distribution of intensive (connected with cattle) and extensive grasslands (both types of farming). The bird community was most abundant and species rich in farmland which provides small fields in large blocks of farmland and many kinds of crops, including both intensive and extensive grasslands. Overall permanent grasslands with rather simply vegetation diversity can maintain a diverse community of spiders and leafhoppers, and act as overwintering habitat for polyphagous predators in field ecosystems. The ecological requirement of all species and species groups are probably never met at one site and consequently target should be in having differently managed areas at regional scale. For some of the taxa, ecosystem services could be indicated, but a research-based quantitative assessment is available only for carbon sequestration and weak impact of dung-beetles in diminishing GHG emissions from cow pats. Our review demonstrated that quite much is known about biodiversity in extensively managed grasslands, but very little in intensively managed grasslands. An important question is whether there is some threshold for the proportion of grasslands under which regional biodiversity will be reduced. Intensive production offers limited value to replace the high biodiversity value of semi-natural pastures.
\end{abstract}

Key words: regional segregation, vascular plants, mammals, birds, predatory invertebrates, coprophages, pollinators, soil biota, ecosystem services

\section{Introduction}

Ongoing biodiversity loss is linked to more intensive and expanding land use and to consequent degradation of land and freshwater ecosystems (Díaz et al. 2019). These changes in nature are interacting with global climate warming and thus strengthening the adverse development (IPCC 2014, Díaz et al. 2019). Globally food production plays a key role in land-use change. One sector of agriculture which demands extensive land areas and causes harmful emission into both air and waters, and thus is shown to influence negatively biodiversity and global climate, is ruminant husbandry. However, the impacts vary among regions.

Globally, the major threat for biodiversity and climate change regarding livestock production is conversion of forests to grazing lands. In regions where agricultural land has been in cultivation for a long time, like in the countries of the European Union (EU), this is not the case. In the EU, the area of forests and other wooded land showed an increase of 5.2\% between 1990 and 2015 and a loss of 6.5\% for agricultural land between 2010 and 2016 (European Union 2018). Also in the EU, livestock production causes a serious threat for biodiversity by contributing $78 \%$ of the total impact of their agriculture on terrestrial biodiversity loss (Leip et al. 2015). However, this threat is targeted to species of agricultural environments due to both simplification of landscapes through 


\section{AGRICULTURAL AND FOOD SCIENCE}

J. Tiainen et al. (2020) 29: 68-97

intensification of the use of agricultural lands and loss of semi-natural or natural habitats through the historical and ongoing land use change (Reid et al. 2010). Therefore, the current impacts of ruminant husbandry on biodiversity of the EU countries are mainly regulated by the intensity and extent of grazing and grass production in permanent agricultural lands.

The negative impacts on biodiversity considerably vary between the levels of intensity of grass production. The intensity increases from semi-natural meadows through hay fields to silage and green fodder production (Blüthgen et al. 2012, Simons et al. 2015, Gossner et al. 2016, Mangels et al. 2017, Schöps et al. 2018). The major management factors affecting biodiversity are fertilisation, grazing and cutting (Plantureux et al. 2005) as well as modes of regeneration, use of agri-chemicals and inter-annual variation in land-use intensity (Birkhofer et al. 2008, Allan et al. 2014). The impacts of ruminant husbandry are not all negative. Moderate grazing is known to have positive effects on species diversity (Metera et al. 2010). Further, increasing the efficiency of production by high quality feeds can save biodiversity by requiring less land to support an equivalent amount of livestock (Herrero et al. 2013).

In this study, we aimed at reviewing the effects of intensive grass cultivation on species diversity of agricultural ecosystems and surrounding watersheds in Finland. Intensity is usually defined as management where higher levels of labour, resources like agrochemicals and capital are used compared with extensive management (e.g. Plantureux et al. 2005, Allen et al. 2011). We cannot make a clear statement which is intensive and which is not, and therefore we study grasslands as a loosely defined continuum from the intensive end to the extensive one. Clearly, agricultural intensification has context-dependent negative impacts on biodiversity (Table 1). In Finland, however, the intensity of agriculture is relatively low in terms of land use (agricultural land covers only 7.5\% of land area; Natural Resources Institute Finland 2019c). Therefore, unlike in central and western Europe, here agricultural land enriches the landscape and habitat diversity, but harmful impacts on biodiversity can be seen with agricultural intensification.

Table 1. Practices of agricultural intensification on local (farm and landscape) and regional scales.

\begin{tabular}{|c|c|c|c|c|}
\hline Practices of intensification & Impact on biodiversity & Impact scale & $\begin{array}{l}\text { South and } \\
\text { west Finland }\end{array}$ & $\begin{array}{l}\text { East and } \\
\text { north Finland }\end{array}$ \\
\hline $\begin{array}{l}\text { Farmers specializing on one or few } \\
\text { (arable) crops instead of mixed farming }\end{array}$ & Decline of intensive grass production & $\begin{array}{l}\text { Local and } \\
\text { regional }\end{array}$ & Yes & No \\
\hline $\begin{array}{l}\text { Farmers specializing on milk or beef } \\
\text { production }\end{array}$ & $\begin{array}{l}\text { Preservation of grass production, } \\
\text { grazing and habitat availability }\end{array}$ & $\begin{array}{l}\text { Local and } \\
\text { regional }\end{array}$ & Little & Prevailing \\
\hline $\begin{array}{l}\text { Cultivating formerly abandoned area } \\
\text { (old fields, fallows) }\end{array}$ & Decline of extensive grass habitat & Local & Yes & Yes \\
\hline Grass production for silage and fodder & $\begin{array}{l}\text { Increasing intensity of grass } \\
\text { production }\end{array}$ & $\begin{array}{l}\text { Local and } \\
\text { regional }\end{array}$ & Little & Prevailing \\
\hline Spreading dung in liquid form & $\begin{array}{l}\text { Nutrients readily available for plants, } \\
\text { environmental effects decrease, } \\
\text { decline of food resource for } \\
\text { coprophages }\end{array}$ & Local & Yes & Yes \\
\hline $\begin{array}{l}\text { Reallocating land to increase field } \\
\text { size, make farms more compact and } \\
\text { minimize edge habitat }\end{array}$ & $\begin{array}{l}\text { Simplification of landscape structure, } \\
\text { decrease of low-intensity grasslands } \\
\text { (field margins) }\end{array}$ & $\begin{array}{l}\text { Local and } \\
\text { regional }\end{array}$ & Yes & Yes \\
\hline $\begin{array}{l}\text { Giving up traditional, low-intensity land- } \\
\text { use management }\end{array}$ & $\begin{array}{l}\text { Decrease of low-intensity, often } \\
\text { meagre grasslands }\end{array}$ & Local & Yes & Yes \\
\hline
\end{tabular}

We covered different biodiversity aspects of ecosystem, such as flora, fauna, soil biota and water environment and indirect effects due to addition of nutrients. We paid attention to regional and local (landscape and farm) levels as far as the available literature allowed. As the effects can be historical, i.e. the habitat for natural biota changed already during former intensification (Vainio et al. 2001), we reviewed also literature of extensively managed 


\section{AGRICULTURAL AND FOOD SCIENCE}

J. Tiainen et al. (2020) 29: 68-97

grasslands for comparison, such as more traditionally cultivated grass fields and semi-natural meadows. Literature on set-asides, fallows, field margins, and buffer zones also provides reference information, as well as management of seminatural meadows with cattle grazing or late-season cutting. We expected the amount of information on biodiversity impacts to differ between the groups of organisms and biodiversity of grasslands to be declined because of intensification. Results are discussed in relation to provision of ecosystem services.

Information produced by this review helps to detect the gaps in the knowledge to be filled with future research, to understand the reasons for the loss of biodiversity in grasslands. In addition, it can help to develop methods to enhance biodiversity. In our view, there is an urgent need for a holistic view on such information. Namely, even though domestic consumers and international trade partners demand sustainability and animal welfare for ruminant (and other food) production (e.g., Kykkänen et al. 2014 and references therein), such as effects on biodiversity and carbon balance, the biodiversity aspect has often been neglected in the current discussion which rather focuses on climate change. One reason may be that available information on the impacts of intensive cattle production on species diversity in Finland is scattered in various journals and partly in grey literature.

\section{Dairy and beef farming in Finland}

Currently, dairy farming is the most important and competitive form of production in the Finnish agricultural sector. In total, Finnish dairy milk production volume accounts for slightly less than $2 \%$ of the production volume in the EU. The number of dairy farms in Finland declined by 27\% (2500 farms) during 2012-2017 due to structural development (see Suppl. Table 3), but at the same time, the amount of milk delivered to dairies has increased by 5\% (Natural Resources Institute Finland 2019a) and, in 2017, dairies received 2366 million kilos of cow milk from approximately 7000 Finnish dairy farms. As a result of EU's Common Agricultural Policy, the role of ruminant husbandry has decreased especially in southern and southwestern Finland (roughly the support areas A and B). The result has been regional segregation into "cereal Finland" and "milk Finland", but there can also be found specialisation into either cereal cultivation or animal husbandry at farm level within regions (for regional division, see Suppl. Fig. 1).

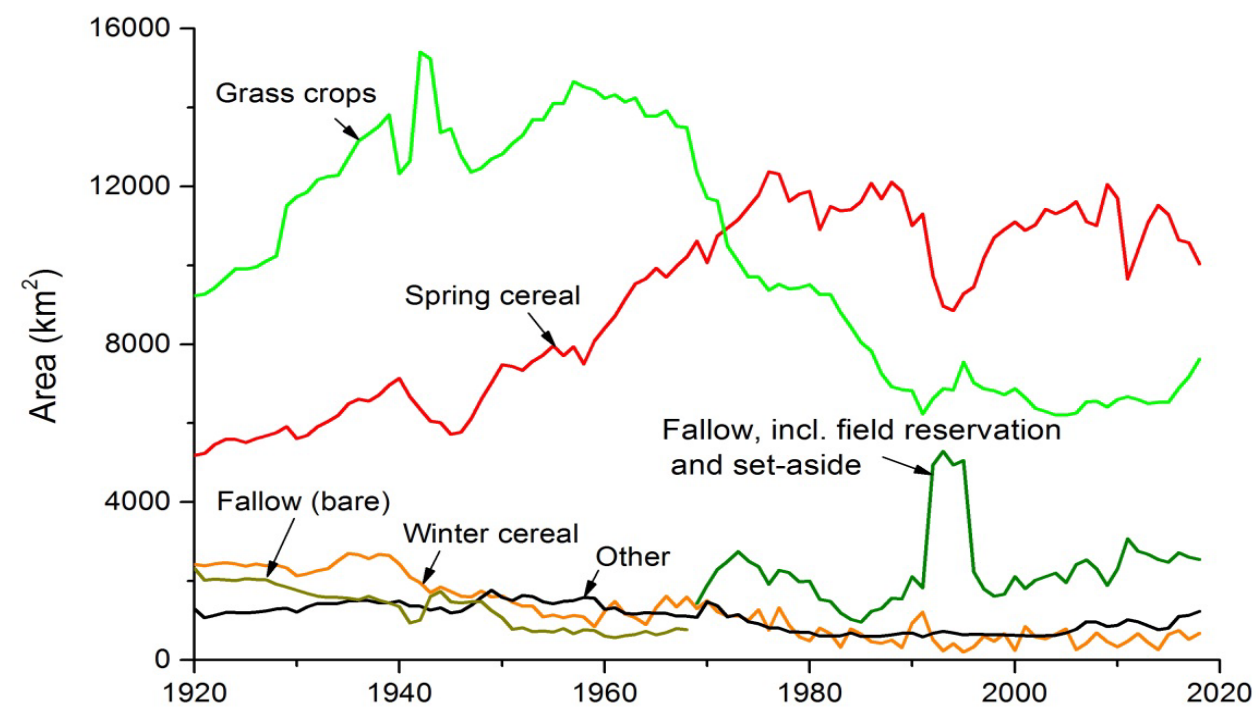

Fig. 1. Use of arable land in Finland in 1920-2018 (Tiainen 2004 and unpubl., based on annual farm statistics of Official Statistics of Finland). Grass crops include dry hay, green fodder, silage and cultivation of hay and clover seed (see Fig. 2). Spring cereal combines spring wheat, oat, barley and mixed cereal. Winter cereal combines winter wheat and rye. Other includes, among other minor crops, potato and oilseed and turnip rape. Fallows were mostly used for mechanical control of weeds to the end of the 1960s and were thus interpreted to be mainly bare. Since 1969 there have been several phases of reducing overproduction with fallowing, like the field reservation program from 1969 to the late 1970s and early 1980s, obligatory green-fallowing in 1991-1994, and 10\% obligatory fallowing during 1995-2007; these fields were mostly established with grass. Since 2008, farmers have been able to make agri-environmental commitments about nature management field grasslands.

Finnish agriculture has gone through tremendous changes during the past 100 years. The ley area increased during the first half of the $20^{\text {th }}$ century in Finland, being about 1.5 mill. ha in the $1950 \mathrm{~s}$ (Fig. 1). It started to decline in the middle of the 1950s to the present (2013) 650000 ha (see Tiainen 2004 for an earlier overview). The proportion of leys of whole field area was about half in the 1960s being now below $30 \%$. The distribution of leys is uneven as its 


\section{AGRICULTURAL AND FOOD SCIENCE}

J. Tiainen et al. (2020) 29: 68-97

proportion of utilized agricultural area (UAA) varies from about 10-15\% in the southwest and south to $50-70 \%$ in the northwest or even $84 \%$ in Lapland (Suppl. Table 1, based on territorial division presented there in Suppl. Fig. 1).

In Finnish dairy and beef farms, grass production is usually integrated into crop rotation where, after a few years of grass, the field is renewed usually for cultivation of cereals or dicot crops. In such a system, grass production is referred to as 'ley farming' in grassland literature. New grass is typically sown using cereals as cover crop or directly on tilled soil. The grass field can also be long-term (over 5 years) or permanent, but then it is regarded as less intensive than grass in the rotation. The impact of grass production on biodiversity depends on the ways of management and harvest. E.g., when fallows with or without legumes are used for improving the soil, beneficial plants in that stage can stay as weeds in the following crop. Considering grass, it is usually so competitive that most weeds do not thrive well. Generally, it is well documented in grassland science that, in addition to natural factors, different forms of grass production - grazing, hay, silage or green fodder - affect the relative competitiveness and survival of plant species in vegetation. Crop fields usually suffer from pest herbivores, but these are controlled by many kinds of avian and invertebrate predators. Instead, grass is more resistant against pests.

In the management of Finnish grasslands, grazing may take place during the whole growing season or after the cut of hay, silage or green fodder crops. Extensive grazing may also be used for managing semi-natural meadows and over 5-year-old grasslands. The use of grasslands for hay (and hay seed production), silage and green fodder and for pastures has experienced considerable changes during the decades (Fig. 2). Most of grassland was used for hay and seed cultivation still in the 1960s, but now their proportion varies between 8-23\% in different parts of the country (Raatikainen and Raatikainen 1975, Suppl. Table 2).

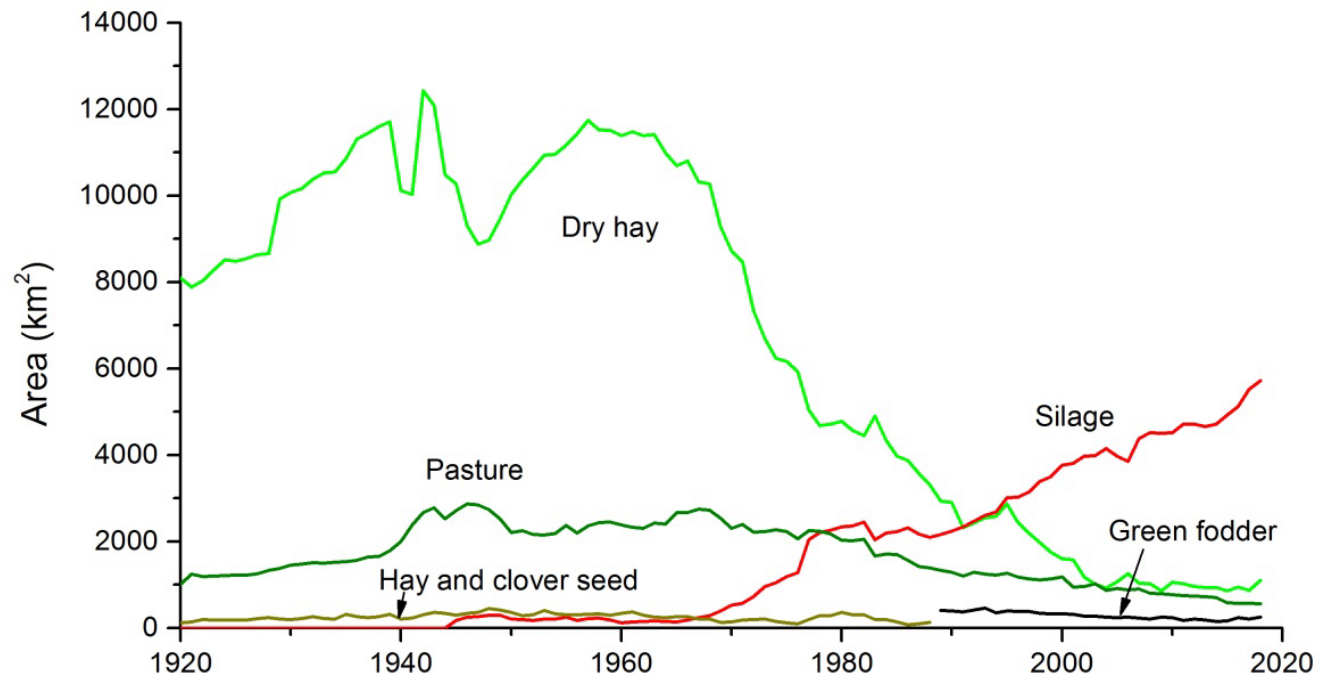

Fig. 2. Cultivation of grass crops in Finland in 1920-2018 (based on farm statistics of Natural Resources Institute Finland 2019c). The statistical record combines green fodder and hay and clover seed cultivation into green fodder starting from 1989.

Formerly, Finnish farms used to be mixed, i.e. they cultivated cereals and kept dairy cattle. Still in the 1960s, almost $80 \%$ of farms had cattle but, thereafter, the number of and proportion of dairy farms dropped dramatically (Suppl. Fig. 2). The decline of the number of farms and the proportion of cattle and dairy farms continues (Suppl. Table 3). In 2017, there were about 275000 dairy cows in Finland. At that time, a Finnish farm had an average of 37 dairy cows, but $52 \%$ of the farms had at least 50 dairy cows (Natural Resources Institute Finland 2019b). The concomitant increase in herd sizes reduces the opportunities to arrange grazing. The new investments for dairy production are most typically based on automatic milking systems (AMS) and have either 60 cows (one AMS unit) or 120 cows (two AMS units). In 2015, ca. quarter of milk produced in Finland came from AMS farms. This together with the scattered field structure has led to a very low proportion of pastures on dairy farms (Virkajärvi et al. 2015).

Contrary to many European countries, permanent pastures are very few in Finland covering only $4 \%$ of Finnish agricultural land. In the first half of the $20^{\text {th }}$ century the mean age of leys had declined from 5 years to 2.4 years ( 2.3 years in southern and 3.0 years in northern Finland, respectively) probably due to a more diverse and regular crop rotation (Raatikainen and Raatikainen 1975 and references therein) and then the trend is increasing possibly in line of specialization instead of mixed farming. The rotation time may have an impact on biodiversity. Based on the Field Parcels Registry (Finnish Food Authority), the mean age of leys before new establishment is 4.4 years 
(O. Niemeläinen, pers. comm. in 2015). The short turn-over time is a consequence of a clear decrease in productivity of grasslands in the course of time (Paatela 1953, Virkajärvi et al. 2015 and references therein) and may have an impact on biodiversity.

\section{Biodiversity effects of grass production on organism groups Vascular plants}

\section{Plant communities}

Typical grassland vegetation community is composed of plant species different from that in arable land. In grasslands, main drivers are the lack of frequent soil disturbance, especially ploughing, and repeated defoliation during the growing season. As a result, plant communities of intensive arable farming are favoured by annuals and permanent pastures by perennials (Håkansson 2003).

Use of pesticides is negligible in grasslands, which most likely results in their smaller impact than in arable fields. The use of herbicides on grassland farming takes mostly place in connection with renovation. In case of high weed invasion, especially Elymus (Agropyron) repens, the farmer may apply glyphosate before ploughing. In addition, grasslands are typically established in spring with cover crop and herbicide treatment. According to experts, only a small proportion of grassland is treated with herbicides or fungicides in Finland during the ley years, although exact data are not available. If the pesticide treatment is successfully done, it reduces the density of weed individuals and proportion of weeds in the harvested yield, and markedly changes the composition of their assemblage. Kajan and Nousiainen (2006) reported a 60\% decrease in the number of weed shoots $\mathrm{m}^{-2}$, and Virkajärvi and Pakarinen (2008) reported that weed proportion of herbage dry matter yield decreased from $14 \%$ to $1 \%$ or from $32 \%$ to $12 \%$, respectively. However, these changes may not be reflected straightforwardly in the amount or digestibility of grass yields in following cuts (Virkajärvi and Pakarinen 2008, Virkajärvi et al. 2012).

Some information, mostly from agrological, but also from floristic point of view, is available on plant species of leys in Finland already from the late 1800s and, even on their abundances, from the first decades of the 1900s (for references, see Paatela 1953, Kosonen 1969, Raatikainen and Raatikainen 1975, Raatikainen 1986, Pykälä 2001). The only sampling-based nation-wide quantitative studies were conducted in 1951 (Paatela 1953) and in 1966-1968 (Raatikainen and Raatikainen 1975). Paatela's (1953) data were collected from 251 municipalities in which 20 first leys from the municipality border were selected for sampling (total 4665 leys). Raatikainen and Raatikainen (1975) randomly selected 54 study areas in 87 municipalities where 1620 fields were selected for the study (for details, see Suppl. Table 5).

Paatela (1953) recorded species with at least $0.1 \%$ share of the vegetation in the sample plot, 218 species in total ( 23 not recorded by Raatikainen and Raatikainen 1975). The average was 10-12 species per field in all parts of Finland. The figure is only a third of that of Raatikainen and Raatikainen (1975), which may be due to different criteria for records (presence without abundance demand in the latter study). Paatela (1953) described how the abundance of wild plants increased almost 5-fold at the expense of clovers and timothy with aging of the ley from 1 -year to 5-years and older.

Including sown species, 6 graminids and 3 clovers Trifolium, Raatikainen and Raatikainen (1975) found 27-34 species per field ( $\alpha$ diversity) on different soils with slightly less in North Finland than in South and Archipelago or Middle Finland (Supplementary information: Table 4). The mean total number of vascular plant species was 117 in the study areas ( $\gamma$ diversity; variation 76-156). The total number was 307 species (some listed at the genus level) in the whole country. 207 were not very rare (found on $\geq 1 \%$ of fields studied) (Supplementary information: Table 5). The number of species found in more than one field was 89 on an average (variation 57-112). Of the 307 taxa, $60 \%$ are regarded as belonging to the original Finnish flora, 30\% alien archeophytes (introduced before the early $17^{\text {th }}$ century) and $8.5 \%$ neophytes (introduced after the early $17^{\text {th }}$ century); three species were cereals from previous year's cultivation (some cultivated species belong to archeophytes) and four of those listed at genus level included species of all the classes (species classification according to Hämet-Ahti et al. 1998, see Hyvönen and Jalli 2011).

Raatikainen (1986) compared abundance changes on the basis of biomasses of species which were represented with at least $10 \mathrm{~g} \mathrm{ha}^{-1}$ on an average. Biomasses had been measured in both studies for 179 taxa of which $50 \%$ had increased, $6 \%$ had not changed and $44 \%$ had decreased (biomass increased by $23 \%$ in 17 years as a consequence of increased use of fertilisers and decrease of ley age). Both Paatela (1953) and Raatikainen and 


\section{AGRICULTURAL AND FOOD SCIENCE}

J. Tiainen et al. (2020) 29: 68-97

Raatikainen (1975) described geographical zonation of ley vegetation from south to north. For comparison, Mukula et al. (1969) found 304 plant species from 2088 spring cereal fields in 1962-1964.

Still in the 1960s, the spread of wild plants into field was facilitated by the vicinity of natural vegetation to leys as grass fields had open ditches and field size was small ( 0.38 ha in the south, 0.82 ha in central Finland and 0.72 ha on the north). Raatikainen and Raatikainen (1975) discussed reasons for the high species number as follows. Half of the seed used for sowing in 1966-68 was produced at the home farm or otherwise locally, and its quality did not reach the standard of purity from weed seeds for commercial use (references to original weed seed count studies in Raatikainen and Raatikainen, loc. cit.). Thus in 1955, there were over 33000 weed seeds per kg timothy seed and over 19000 in red clover seed, and in 1963 almost 10000 weed seeds kg-1 of commercial seed. In 1969, the weed seed contents had declined to $39 \%$ in timothy and to $56 \%$ in red clover. One more factor decreasing weed number was active herbicide treatment during sward establishment phase, which slowly became more common.

The few recent studies on weed species of intensively cultivated leys come from a limited geographical area from North Savo and North Karelia. In experiments of the impact of herbicides, Kajan and Nousiainen (2006) recorded 27 dicot weed species (pooled number) in treated and control paddocks in Maaninka, North Savo (Virkajärvi and Pakarinen 2008, Virkajärvi et al. 2012). At the Siikasalmi Research Farm in Liperi (North Karelia), Kuusela and Hytti (2001) and Kuusela (2004) found 22 and 28 dicot weed species in two different experiments on organic pastures, respectively. Superficially compared, the species composition in organically cultivated grassland resembles more the silage plant community without herbicide treatment than with a treatment (Suppl. Table 6).

A proper comparison between these modern studies and older results by Raatikainen and Raatikainen (1975) is not possible, because there are no silage leys in the latter. However, we compiled lists from Raatikainen and Raatikainen (1975) for North Savo and North Karelia, the neighbouring areas of modern studies (Suppl. Table 5; rank order of species listed in Table 6 introduced there). The total number of species (taxa) in these study areas varied from 119-136 (114-126 without the nationally very rare species). In addition to cultivated species, they found many non-sown gramineous species, such as Elymus (Agropyron) repens, Deschampsia caespitosa, Agrostis tenuis, Anthoxatum odoratum, P. trivialis, and Festuca rubra that were classified as very abundant or abundant. In recent studies, the most abundant gramineous non-sown species seem to be different, although not as well documented, i.e. E. repens, P. annua, Alopecurus geniculatus and D. caespitosa (Puurunen and Virkajärvi 2005, Kajan and Nousiainen 2006). Therefore, there is some evidence to conclude that intensification of grassland farming has decreased the abundance of several secondary gramineous species.

The intensity of grass cultivation increased during the past decades when silage and green forage replaced hey production. Low-intensity grasslands are nowadays mainly represented by field margins, shelter belts and setasides, as semi-natural meadows are rare.

Field margins function as buffer zones between fields and water courses retaining nutrients and eroded materials. Their plant community composition was studied by Tarmi et al. (2002, 2009, see also Ma 2005, 2006). The recorded plant species were mainly indicators of fresh to wet soils and moderate to rich mineral nitrogen content, the most frequent species being tall and mostly herbicide-tolerant perennials. The vegetation was productive, but not diverse. They identified six community types, with 24 species in the species-richest and 14 or 16 species in the two poorest types. In animal husbandry regions, the most frequent species were sown grassland species and typical grassland weeds, whilst in cereal production regions, fast-spreading root weeds tolerant of herbicides were the most frequent. The origin of field margin species was rather similar to that in hay-fields (see above), as somewhat under two thirds of field margin and grassland species were natives, about one third archeophytes and some few percent neophytes in four study areas in different geographical areas (Jauni and Hyvönen 2010, Jauni 2012). On long-term ( $>5$ years in experiments), species richness can be increased by widening the boundary zones and with proper management (cutting and removal of remains) (Tarmi 2011, Tarmi et al. 2011, Tarmi and Hyvönen 2012).

Short-term fallows are usually established with grass and they resemble leys, but long-term fallows are often left alone for years after cultivation. A period of long-term fallowing was conducted in Finland in the 1970s and 1980s. Between 1969-1974, 240000 ha of fields were left uncultivated with 15-year contracts; these became grasslands many of which were later abandoned or afforested. The vegetation and its succession of such reserved fields were studied by Törmälä and Raatikainen (1976), Hokkanen and Raatikainen (1977a), Hokkanen (1979), Törmälä (1982a), Jukola-Sulonen (1983) and Pullinen (1986) (see also Berg et al. 1978). After cereal crops, the vegetation was dominated by weedy dicot species, but in a few years graminids and Achillea ptarmica and Ranunculus repens totally replaced the weed dominated community (Hokkanen and Raatikainen 1977a, Törmälä 


\section{AGRICULTURAL AND FOOD SCIENCE}

J. Tiainen et al. (2020) 29: 68-97

1982a). Hokkanen and Raatikainen (1977a) distinguished five vegetation types in the succession series: Galeopsis -type, Phleum-type, Anthoxanthum-type, Deschampsia-type and Elytrigia-type. After ten years in a more moisture fallow, tussock-forming Deschampsia cespitosa had replaced Festuca, Phleum, Agrostis and Poa which do not form tussocks (Törmälä 1982a). Jukola-Sulonen (1983) found that species diversity increased during the course of succession of afforested fallows until trees became dominating. She divided the species, according to a twofactor varimax solution, into three successional groups.

\section{Impact of management on vascular plants}

In comparison to intensively managed grasslands, extensively managed grasslands are species rich (Hokkanen et al. 2006c, Pykälä 2007), but their preservation depends of proper management (Jutila 1999a, b, Pykälä 2001, Hägg et al. 2006, Pessa et al. 2006, Piippo 2010). On a meadow pasture, which had formerly been intensively managed ley and probably impoverished seed bank, the species number declined during an 11-year pasturing experiment (Hokkanen et al. 2006c). Raatikainen et al. (2007, 2009) showed that factors related to land-use intensity and high nutrient level (especially P) had a major role in explaining the species composition of vegetation of semi-natural grasslands both at 0.25-ha and 1-sq.m scale, but also soil heterogeneity and habitat characteristics (patch area, connectivity, exposition) accounted notably.

Traditional and modern management method impacts on biodiversity of grassland or field boundary and buffer zone plant communities were studied by Jantunen (2003a, b), Jantunen and Saarinen (2002, 2003), Jantunen et al. (2003), Pykälä (2007), Tarmi (2011), Tarmi and Hyvönen (2012) and Tarmi et al. (2002, 2009, 2011). Mowing and grazing have different impact on species richness, since many of the species are small and not competitive with large herbs or graminids (Jantunen 2003a, b, Jantunen and Saarinen 2002, 2003, Jantunen et al. 2003, Pykälä 2003, 2004, 2005, Pykälä et al. 2005). Thus, Huhta (2001) and Hellström (2004) showed that the appearance and structure of a traditional grassland rich in small-growing herbs can be restored in five years, but it is more difficult to increase species diversity by mere mowing or grazing, probably because of limitation of seed bank in soil. It can be argued that herbage removal is the most important factor affecting species dynamics in biotopes managed by grazing (Kurtto 1993, Dorrough et al. 2006). Besides vascular plants, also bryophytes benefit of grazing (Takala et al. 2014). A possible threat to the semi-natural plant community can be caused by alien neophyte species, but Jauni et al. (2012) and Jauni and Hyvönen (2012a, b) found the threat small.

In the light of the recent studies, the plant species diversity in intensively managed grassland is not very high and the species provide a limited value for other species groups. For example, common dicot weeds often occur on grasslands and their proportion increases with the ley age (e.g. Taraxacum spp., Ranunculus spp., Rumex sp., Stellaria media) (Puurunen and Virkajärvi 2005, Virkajärvi and Punkki 2007, Virkajärvi et al. 2012). Flowering Taraxacum spp. have nutritional value for flower-visiting insects, like bees, bumblebees and syrphids. Most likely the secondary grass species (Festuca rubra, Poa pratense) or grass weeds (e.g. Elymys repens, Poa annua) do increase the botanical value of the vegetation even less than dicots. However, they affect the resilience of the vegetation for biotic and abiotic stresses which may be of importance in some occasion. Multispecies grassland has gained a lot of attention in recent years but mainly from agronomical rather than biological point of view (Finn et al. 2013, Ergon et al. 2016). It is worth of mentioning that in some parts of Central Europe a high proportion of dicots is considered desirable for grasslands (e.g. Spatz and Baumgartner 1990, Wilman and Riley 1993, Wyss and Vogel 1998) but not in most intensive systems (Haugland 1995, Elsässer 2004).

According to nutrient balances, grazing with beef cattle removes a relatively small amount of minerals compared with the whole nutrient (N, P) cycle (Virkajärvi et al. 2006a, Niemelä et al. 2008, Niemelä 2009). Instead, changes in intensity of nutrient cycles and nutrient availability due to grazing are most likely a more important factor affecting the pasture ecology (Hokkanen et al. 2006a, Virkajärvi et al. 2006a). While grazing is a preferable method for the management of semi-natural grasslands, the food availability for cattle is typically low, but may be substantial on meadows on soils with favourable soil moisture and fertility (Virkajärvi et al. 2006a, b). Extra forage cannot, however, be provided in large amounts because eutrophication is a threat for small endangered plant species (Niemelä et al. 2008) and, therefore, semi-natural grasslands cannot be used as dairy cattle pastures. However, provision of concentrates to calves for short periods appeared to have negligible effects on the P balance of natural pastures (Virkajärvi et al. 2006a, Niemelä et al. 2008). Therefore, pasturing of young calves or heifers is not against the principle of plant diversity management on meadows and wooded pastures. The possibility to give supplemental feed to calves and heifers while grazing on semi-natural meadow pastures improves 


\section{AGRICULTURAL AND FOOD SCIENCE}

J. Tiainen et al. (2020) 29: 68-97

the likelihood of combining modern agriculture and management of traditional biotopes. In general, semi-natural grasslands provide better possibilities for beef cattle than for dairy cattle because of their lower production intensity, larger intake capacity and higher tolerance for low quality feed.

\section{Vertebrate fauna}

\section{Mammals}

The main potential wild vertebrate herbivores in cultivated grasslands are the field Microtus agrestis and common vole M. arvalis, brown hare Lepus europaeus and three species of cervids (moose Alces alces, roe deer Capreolus capreolus and white-tailed deer Odocoileus virginianus). Among them, especially the field, but also common, vole can cause damage to cultivated grass crops and, therefore, their ecology was earlier studied by Myllymäki (1959, $1975,1977)$ at the Agricultural Research Centre. The research into the impact of other herbivore species on leys, hay fields and other crops is scarce in Finland, and no quantitative assessment is available of their abundance in grasslands seasonally or spatially. However, the small mammal community was studied 1-6 years after grass or cultivation in 51 fallows in central Finland in one year. Sorex araneus and Microtus agrestis made up $90 \%$ of all species in the small sample $(n=167)$ (Hokkanen and Raatikainen 1977b).

The research into voles used to be concentrated on damage caused in different crops (and orchards). Completed with food choice tests, the surveys provided, however, information on habitat selection of voles (Myllymäki 1959, $1975,1977)$. The main species in hayfields were the field vole and common vole. Their most preferred food plants were Taraxacum spp., Leontodon autumnalis, Sonchus arvense, Trifolium spp. and Medigago spp. Among monocots, many graminids, like Festuca pratensis, timothy grass Phleum pratense, Dactylis glomerata, Agropyrum repens and Deschampsia flexuosa were preferred (Myllymäki 1959). In hay fields and leys, both the field vole and common vole selectively grazed on clover in mixed stands of red clover Trifolium pratensis and timothy grass (Myllymäki 1975, 1977). Jukola-Sulonen (1983) expanded the list to the second and third stages of preference. Now, when most of these mixed leys have disappeared (cattle are often fed with grass and additional protein concentrates), this type of vole damage has lost its importance (Myllymäki 1975).

The main habitats of the field vole often represent secondary successional stages (Hansson and Myllymäki 1973, Hansson 1977). In southern Sweden, leys belong to low density habitats but, in northern Sweden, they are temporary high-density areas (Hansson 1977). In Finland, the highest reproduction survival and density values are found from mixed grass-forb state on mineral soil (which may be called a mesic grass-tall forb stage in secondary succession; Myllymäki 1975, Hansson 1977).

The field vole has territorial and resource competitive interactions with common vole, but in addition also with two other arvicolid voles, the European water vole Arvicola amphibious (syn. A. terrestris) and bank vole Clethrionomys glareolus. Interaction of field vole on the one hand and the bank vole or water vole on the other is most likely to occur in permanent grassland habitats on mineral soil, i.e., favourite production habitats of the field vole (Myllymäki 1977). However, the common vole is not very common in Finland, and the water vole prefers moister environments. The ecological ranges of the field vole and bank vole are most likely to overlap outside the breeding season, e.g., in forest regeneration areas, but not in leys because of space competition (Myllymäki 1977, Eccard and Ylönen 2002). Even though the bank vole is clearly a forest species, it may also expand its range to old-fields in the absence of the field vole (Ylönen et al. 1988).

Yletyinen and Norrdahl (2008) studied the abundance and habitat use of field voles in narrow filter strips (5-m wide) and broad buffer zones ( $>15-\mathrm{m}$ wide). They found that field margin width had a significant impact on the use of available habitat in terms of home range size and distances moved. Voles in the filter strips used crop fields significantly more than voles in buffer zones. There were no clear seasonal differences in the proportional use of crop field and buffer zone.

Arvicoline rodents commonly undergo 3-5-year cyclic fluctuations in population density which is commonly believed to be a result of combined effects of predation and winter food limitation in pronouncedly seasonal environments with long winters (see Huitu et al. 2007). Norrdahl et al. (2002) and Huitu et al. (2003) experimentally studied the indirect effects of vertebrate predation exclusion on plant communities in old-field grassland in Lapua.

The design included treatment combinations with and without predation and supplementary feeding. It was found that the removal of the top trophic level resulted in a major increase in vole densities, but the expected trophic cascade rapidly attenuated so that the indirect effects of predator exclusion were restricted to a few plant species. 


\section{AGRICULTURAL AND FOOD SCIENCE}

J. Tiainen et al. (2020) 29: 68-97

The cause for the rapid attenuation of the trophic cascade appeared to be strong seasonality, as peak densities of voles were attained at the end of the growing season of vegetation, and vole populations declined before the next growing season so that the herbivory pressure during the growing remained low or moderate. Accordingly, most plant species escaped the heaviest grazing pressure either in time (plants completed their reproduction before winter) or in space (living parts hidden under frozen ground and ice). However, heavy winter herbivory reduced the biomass of available vegetation (like willows, Salix sp.) during vole peaks. During summer, voles reduced the coverage of only a few preferred food plants (Elymus repens, Phleum pratense, Vicia cracca). On the other hand, voles maintained annual and biennial species in the community by creating gaps in the closed vegetation. Norrdahl et al. (2002) concluded that abiotic factors (harsh winter conditions) limited peak numbers of herbivores below a threshold density where the herbivores could have caused a community-level decline in the biomass of herbaceous plants during summer. Huitu et al. (2003) concluded that the results indicate that Microtus vole populations that have succeeded in escaping regulation by predators are limited in growth by lack of winter food.

The diet and habitat of the brown hare has been studied in different parts of Europe, but there are only few Fennoscandian studies of habitat selection and food (Hyytinen 1974, Frylestam 1980, 1986, 1990). The brown hare lives in agricultural areas where the best feeding opportunities are found in mixed farmland with different kinds of food available in all seasons. The preferred summer food is comprised of various wild and cultivated dicots and grass (Frylestam 1990). Grasslands are an essential part of its habitat.

Hyytinen (1974) studied winter nutrition of the brown hare in the immediate surroundings of Oulu and Kokkola in the winters of 1968/69 and 1969/70. Depending on availability in different study plots, in early winter the hares mainly consumed green parts of timothy Phleum pratense from under snow, stalks of red clover Trifolium pratense and also leaves of Poa sp. and capitula of Achillea ptarmica, twigs of willow Salix sp., as well as hay from barns and Brassica oleraceae. In late winter when the snow cover was too thick, the main source of food was dry hay, but also willows and capitula of different composite species were important, as were also the species of early winter food if available.

Frylestam (1986) studied the winter diet in relation to agricultural land use in three different farmland types (pastures, mixed farmland and monoculture land) in southern Sweden. In stomachs collected in October - December, 37 plant species or genera were recognized, 20 of which were graminids and the others were herbs. Grasses were most frequent at this time of the year and were highly utilized in pastures and mixed farmland. In all areas wild plants were preferred to cultivated crops, indicating the importance of a rich wild flora available to hares. In mixed farmland they had better access to wild plants which were also preferred whilst in monocultures they used cultivated plants more. The hares thrive well in northern winter climate, if the landscape structure is small-scale and there are fields (leys, winter cereals, set-asides, buffer zones) which provide green shoots of herbs and monocots which the feeding animal digs from under the snow (Hyytinen 1974, Frylestam 1986). A similar study from Austria, including samples from February, May, August and November, gave rather similar results, i.e. in autumn and winter the hares preferred cultivated crops, but in spring and summer wild herbs (Reichlin et al. 2006).

Roe deer, white-tail deer and moose also use farmland, but they are not so much after grasslands. Their diet, as far as it concerns vegetation on fields and cultivated plants, consists mostly of turnip rape Brassica rapa, oilseed rape $B$. napus and winter cereals. From grass fields, clovers are most desired food (Cederlund and Liberg 1995).

Birds

Knowledge on Finnish farmland bird population and community composition changes is based on censuses which were made since the 1930s. In 1984, the original farmland study areas of Soveri (1940) were re-censused in Lammi (Tiainen et al. 1985, Tiainen and Pakkala 2001). From that year annual monitoring lasting until 2013 was started on Soveri's original study plots totalling 1300 ha. In 1984 also other earlier farmland bird censuses from the 1950s, 1960s and 1970s were repeated (Mehtälä et al. 1985, Ylimaunu and Siira 1985, Yrjölä et al. 1986). These studies convincingly show that bird communities have greatly changed with agricultural land use changes. Results from these studies are presented in the Supplementary information. More recently and as a part of evaluating the biodiversity impact of agri-environmental schemes and sustainable optimisation of farmland use, the research was extended to cover large areas of southern and central Finland (Tiainen et al. 2004b, 2012b, 2014, and unpubl.) and Åland Island in 2001 with representative sampling (Tiainen et al. 2012a). Results of these studies revealed big changes in bird populations and the community and, with environmental data, have allowed analyses of their causes. 


\section{AGRICULTURAL AND FOOD SCIENCE}

J. Tiainen et al. (2020) 29: 68-97

The substantial changes in Finnish agriculture from mixed farming to either specialised cereal or cattle farming both on farm scale, and increasingly regionally led to big changes in the breeding bird community. Thus, many bird species preferring mixed farmland have become rare in southwestern and southern Finland, like the curlew Numenius arquata. The long-term changes since the 1930s of the skylark Alauda arvensis follow the availability of grass, either as leys or fallows (Tiainen et al. 2001, Piha et al. 2003, 2007a). At the same time agriculture has become more efficient both in terms of economy and land use. The result has been a decrease of landscape structure and variation of land use, which are related to bird community diversity (Piha et al. 2007b, c, Ekroos et al. 2013, 2019, Marja et al. 2013, Jonason et al. 2017, Mäkeläinen et al. 2019). With data on twenty species breeding in open farmland, Ekroos et al. (2019) found that increasing proportions of grasslands increased species richness and diversity, whereas increasing proportions of fallows increased bird diversity. Herzon et al. (2011) found that species richness and density of open-country farmland birds were twice as high in set-asides as in cereal fields when the impact of landscape structure was controlled. Of grasslands, reed canary grass Phalaris arundinaceus has been shown to be an adverse breeding habitat for birds because of its dense sward (Vepsäläinen 2010). The changes in farming and landscape also explain a part of bird population changes (Piha et al. 2007a, b, Vepsäläinen et al. 2005). In small fields with a landscape surrounded by near forest, the bird community rapidly developed towards bush and wood assemblage (Törmälä 1980).

Hitherto, we have only a descriptive analysis of breeding bird densities in different farmland habitats (Fig. 3). For all species, more or less natural grassy habitats appear most important. Among leys and tilled fields, which host mainly species of open country, pastures and leys rank after stubbles, directly sown fields and autumn cereals before fields tilled in spring. For farmland species breeding outside the fields, pastures and leys are not important for breeding though they can be essential for feeding (like for the Starling, see below).
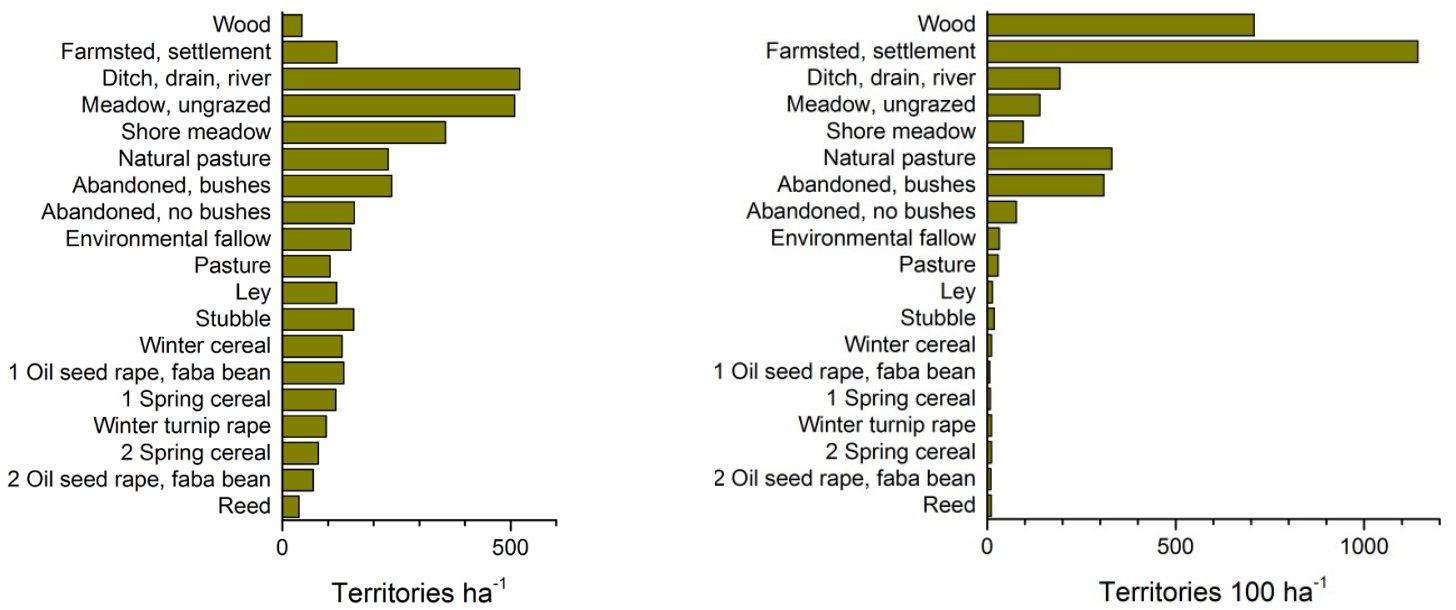

Fig. 3. Breeding density of farmland birds of open habitat (left) and farmsteads, settlements and forest edge (right) in 20092011 (based on 26815 bird territories and censuses on 9926 ha of farmland; number of species 16 and 20, respectively) (redrawn from Tiainen and Seimola 2014). 1 and 2 for spring cereal and oil seed rape and field bean refers to direct sowing and sowing with tillage, respectively.

Many farmland species benefit of a variable landscape which was typical for dairy farms with diverse use of fields and animals going to the pasture. Species of open fields use different fields during the breeding cycle depending on the development of the sward. As an example, the curlew feeds on leys and pastures in the early part of the breeding season, but changes to cereal fields when the soil of the former becomes too hard for penetration of the bill for food search (de Jong 2012). The population increase of the curlew in Kauhajoki did probably not relate to farming changes but released hunting pressure in wintering areas, though a later long-term decline of south Finnish curlew populations seems be due to farming changes, i.e. decline of grasslands (Valkama and Currie 1999, Valkama et al. 1999). Kuitunen et al. (2003) studied the composition of the farmland bird community at regional scale by comparing census results from Finnish and Russian Karelia from 1998 and 1999. They stated that during the last 50 years, human impact on agricultural environments has drastically differed between Finnish and the adjacent Russian Karelia. Finnish agriculture became more intensive and efficient (new cultivation methods, subsurface drainage, use of agri-chemicals), while the corresponding changes have remained smaller in Russian Karelia. In the Russian Karelian study region, cereal cultivation was rare, abandonment and overgrowth of fields common and dairy farming still constituted the most important agricultural sector. However, the composition and abundance of species in general was rather similar on both sides of the border. 


\section{AGRICULTURAL AND FOOD SCIENCE}

J. Tiainen et al. (2020) 29: 68-97

The species favouring scrub and pastures (corncrake Crex crex, Starling, yellow wagtalil, Motacilla flava) were more abundant in Russia whereas species benefitting from cereal cultivation (ortolan bunting, Emberiza hortulana, yellowhammer, E. citrinella) and the openness of fields curlew were concentrated in Finland. Kuitunen et al. (2003) concluded that changes in agricultural policy, including the impact on abandonment of mixed farms (dairy and cereal) in Finland are likely to change this pattern.

At the landscape level, on which the above censuses were made, many causes can be identified behind the bird population changes including, in addition to the substitution of dairy farming with mainly cereal cultivation, abandonment of cattle pasturing, subsurface drainage, unification of fields to larger units, disappearance of verges, and use of agri-chemical with its implications. The above evidence is also only descriptive and correlative. However, the Starling case was analysed more profoundly with modelling (Rintala and Tiainen 2008).

The Finnish starling population had decreased for long (Solonen et al. 1991), and Rintala and Tiainen (2007) assessed the magnitude of the decline at $80 \%$ during two decades from the 1960 s to the 1980 s. The ecological background appeared to be in reproductive success as revealed in an experimental study with six starling breeding populations (Tiainen et al. 1989). Only $25-40 \%$ of nestlings fledged in habitats without pastures within 500 meters from nests, but 75-90\% from nests where pastures were available (the starling searches food for nestlings from the soil surface of short grass). In a study with the same populations, Varjonen (1991) showed that travel distances to food searching sites decreased with increasing food demand of growing chicks allowing more frequent food provision in populations close to pastures compared with populations where pastures were not available in the vicinity. This explained the difference in breeding success.

In the modelling study (Rintala and Tiainen 2008), it was assumed that the carrying capacity K of breeding habitats decline especially in southern Finland, because the amount of poorly productive starling habitats (sinks) increased at the expense of highly productive ones (sources). Nestling ringing data from 1951 to 2005 were used to estimate trends in brood size and population change. The results showed that the brood size was greater during stable population stages (at the beginning and end of the study period) than during the years of collapse. The coefficient of variation displayed a contrary pattern to the mean brood size, being at its highest during the decline. The relation of population dynamics and environmental change was modelled with a density-dependent matrix model that assumed an $80 \%$ decline in $\mathrm{K}$ (corresponding to the observed entire population decline). The modelling results obtained were similar to the population dynamics actually observed. The model showed a decrease in per-capita reproductive rate as a response to habitat deterioration. This was due to a time lag in response to the declining $\mathrm{K}$. On the basis of the dynamics observed and the population model, it was concluded that during the decline, a larger proportion of starlings bred in sub-optimal sink habitats (low reproductive success due to lack of pastures in the surroundings of the nest; Tiainen et al. 1989, Varjonen 1991) than during the stable population phases, and that this caused the low in the mean and the high in the coefficient of variation of brood size. Survival analysis on nest-card data (collected by the Natural History Museum of the University of Helsinki) supported the conclusion that the population decline was due to a decreased brood size caused by decreased $\mathrm{K}$.

\section{Invertebrate fauna}

Invertebrates make up the most abundant animal group in grasslands and the other farmland. Many of the species provide ecosystem services such as pest control (both weeds and other invertebrates), pollination, dead organic matter decomposition and food for predatory invertebrates when there are no pests. Conventional farming makes use of these services less consciously, but organic farming is dependent on them (e.g. Geiger et al. 2010, Henneron et al. 2015, Hokkanen et al. 2017, Fan et al. 2018).

Quite many studies were conducted on invertebrates of grasslands. A general survey of beetles in the whole Finland was conducted by Raatikainen and livarinen (1986) in 1966-1968 with sweep-netting for beetle fauna of field layer in the same 54 areas where the vegetation inventory was made (see above). Their team collected a total of 443 beetle species in hay-fields, $12.7 \%$ of the total number of known beetle species in Finland. Of the species whose feeding habits were known, 50\% were herbivores, $16 \%$ carnivores, $3 \%$ carni-herbivores and $31 \%$ fungivores or saprophages. The corresponding values for the total sample of 19214 individuals were 66.4, 23.6, 0.5 and $9.5 \%$, respectively. The composition of the beetle fauna suggested geographical zonation coincident with Finnish vegetation zones. A general survey was made also by Törmälä (1982a, b, 1986) who found 18 and 45 species of leafhoppers (Auchenorrhyncha) in the beginning and at the end of July when comparing five sampling methods in a reserved field (9-year old fallow without management; results of other invertebrate groups were not presented at species level). Törmälä and Raatikainen (1976) found 28 species of leafhoppers during 


\section{AGRICULTURAL AND FOOD SCIENCE}

J. Tiainen et al. (2020) 29: 68-97

the growing season in the fifth year of the same fallow. Also Hokkanen and Raatikainen (1977b) studied the invertebrate fauna on fallow fields $(n=51)$ being reserved $1-6$ years after grass or spring-sown crops. They found 210 invertebrates $\mathrm{m}^{-2}$ on an average in mid-summer with sweep-netting with $42 \%$ of leafhoppers, $18 \%$ of Hymenoptera, $14 \%$ of Coleoptera and $26 \%$ of other groups. The abundance of invertebrates was higher in fallows after grass than spring crops and increased with the age of the fallow, but pests which decreased. The number of leafhopper species found by Huusela-Veistola and Vasarainen (2000) was 37 in perennial grass strips during a four-year study.

\section{Predatory invertebrates}

Few studies were made in modern intensively cultivated leys or in connection of intensive cattle production. Studies with an agronomic focus into insect pests and their natural enemies, especially polyphagous predators such as ground beetles (Carabidae), rove beetles (Staphylinidae) and spiders (Araneae) have been concentrated on arable crops like cereals which have more pest problems than intensive grasslands (leys, swards, silage, grazing).

Effects of semi-natural grasslands and different habitat management systems (e.g. perennial grass strips, fallows, set-asides) on diversity of arthropods were studied during the past decades (Huusela-Veistola 1998, 2000, Huusela -Veistola and Hyvönen 2006, Hokkanen et al. 2006b, Hyvönen and Huusela-Veistola 2011, Toivonen et al. 2018). These perennial semi-natural grassland habitats can maintain populations of polyphagous predators by providing alternative prey species and refuges. For example, the number of spiders was clearly higher in perennial un-cut grass strips (sown with a mixture of timothy, meadow fescue, red clover and white clover).

Overall permanent grasslands with rather simply vegetation diversity can maintain a diverse community of spiders and leafhoppers, and act as overwintering habitat for polyphagous predators in field ecosystems. Furthermore, the numbers of polyphagous predators in cereal fields are usually higher near grass strips than further away (HuuselaVeistola 2000). However, perennial fallow grass strips and field margins can promote pest control in spring cereals (Toivonen et al. 2018). Thus, e.g., the buffer strip width affects the abundance of hemipteran assemblage. Gilbert et al. (2015) were interested in the abundance of hemipteran species belonging in the genus Nabis (generalist predators) and potential pests of cereal crops. Riparian buffer width was not associated with hemipteran species turnover, but differences in the degree of dominance by grasses, in plant species turnover, and the cultivated plant species in the adjacent field explained a significant proportion of variance in hemipteran species turnover. The abundance of predatory Nabis species increased with increasing riparian buffer width, whereas the abundance of recognized and potential crop pests decreased. Gilbert et al. (2015) conclude, however, that the management of riparian buffers for the enhancement of biological pest control by predatory hemipterans requires further study.

However, both intensity and type of management in grasslands affect insects and spider communities. Several factors in establishment and management of intensive grassland (e.g. seed mixture, diversity and structure of vegetation, age, intensity of cutting or grazing, cropping history, landscape) may affect abundances, diversity and communities of arthropods. Grazing can increase abundance and species richness of ground beetles and spiders, but this depends on habitats (Halmeenpää et al. 2006, Hokkanen et al. 2006b). Effects of these factors differ between species and these have not been studied in Finland.

Spider communities of leys and winter cereal (rye, winter wheat) fields were studied by Huhta and Raatikainen (1974). Large-scale sampling with sweep netting was carried out representatively in all parts of Finland. They found a total of 61 spider species in leys and 49 in winter cereals (in both samples, the total $n$ was 1133 individuals). In an earlier similar study, Raatikainen and Huhta (1968) found 65 species in oat fields $(n=761)$. The spider communities of leys, winter cereals and oat were strikingly similar, i.e. all three had the same four most abundant species, and many even among the least abundant species in common. However, the total abundance (specimens per sample) was more than twice so big in winter cereals compared with leys and oat, but species diversity (measured with Shannon index) was lowest in winter cereals and did not differ between the other two. Most spiders found belonged to species which prefer high illumination and moisture. The spider community was like what had been found in Estonian and Polish natural meadows (Kajak 1960, Vilbaste 1964, 1965), and it is believed that the farmland spider fauna mainly originates from littoral habitats (including natural meadows) (Tischler 1958).

Carabid beetle (Carabidae, Coleoptera) communities were extensively studied in Lammi, southern Häme in the 1990s. In the first study, several aspects of the assemblage or community diversity were studied at three levels of spatial scale, the field, the patch (block) of farmland (defined as the open farmland area with one or several farms from one forest edge to the other), and between patches lying some kilometers from each other. The studied crops were ley, grassy set-aside, spring cereal, potato and sugar beet. Sampling of carabids was made with pit-fall traps 


\section{AGRICULTURAL AND FOOD SCIENCE}

J. Tiainen et al. (2020) 29: 68-97

throughout the growing season. The main result was that carabid communities significantly varied among patches of farmland but not between fields of different crops within patches (Kinnunen et al. 2001). Only communities in potato fields were found to resemble each other among patches. Thus, the carabid beetle community diversity in leys and set-asides (total number of species 51 and 57, respectively, with a sample size of 1265 and 1832 individuals, respectively) was not different from that of other crop types excepting potato. Varis et al. (1984) had already earlier compared the carabid community of cabbage, sugar beet and timothy fields in one study site. The communities were quite similar, the timothy somewhat differing from the other two habitats.

On the other hand, spatial isolation from other farmland has a significant impact on the carabid assemblage. Kinnunen et al. (1996) studied carabid beetles in Lammi in two years with the focus on isolation of small fields (0.1-4.3 ha) surrounded by forest. The habitat was either ley or set-side sown with a grass mixture. They found that the mean number of species and individuals were largest in large farmland patches and smallest in small isolated patches (total number of species 67 with a sample of 6773 individuals). However, as the sample size varied much the expected number of species for a fixed sample size did not significantly vary. This compares with the study of Hokkanen et al. (2006b) who studied carabids in Tohmajärvi (North Karelia) for four years. They found the total of 43 species (1411 individuals) and 46 species (3480 individuals) in grazed and non-grazed parts of a meadow which had formerly been an intensively cultivated ley.

In a further study area with 150 fields, carabid beetles were sampled with pitfall traps in 27 fields. Here, the carabid community in grassy set-asides differed from other crop types (Kinnunen and Tiainen 1999). Among 8652 individuals and 59 species, almost $70 \%$ of beetles of grassy set-asides belonged to autumn-breeding species, while almost $80 \%$ of individuals belonged to spring-breeding species in fields tilled in spring. The number of autumn breeders increased towards the end of summer. It seems that leys and grassy set-asides provide wintering habitat for autumn-breeding carabid beetles. Ekroos et al. (2010b) found that activity densities of carabid species were higher in conventional mixed farms than in organic or conventional cereal farms.

\section{Dung-inhabiting beetles}

Dung beetles play a central role in decomposition of cow pats on pastures (Hanski and Cambefort 1991). They provide many ecosystem services, such as the recycling of nutrients, the aeration of soil, control of invertebrate parasites and even the dispersal of plant seeds (Roslin et al. 2014). Recent evidence suggests that they may even affect the climate, by modifying fluxes of greenhouse gases from cow pats (Roslin et al. 2014) but the magnitude of the effect is minor (Maljanen et al. 2012). Pastures are important habitats especially for dung beetles, and a widespread loss of pasture habitats may have severe effects on their assemblages (Roslin 1999, 2000, 2001, Roslin and Koivunen 2001). The resources of dung beetles are highly patchy and temporary (cow pats), and the persistence of populations depends on the mobility and dispersal capacity of adult beetles.

Dung is an energy-rich resource for a large community of invertebrate animals, both as food and a habitat for reproduction. Koskela (1972, Hanski and Koskela 1977, 1978, Koskela and Hanski 1977) studied the whole dunginhabiting (adult) beetle community in two study sites in southern Finland with reference to the seasonal, macrohabitat and successional gradients. The data comprised 50 coprophagous and 129 carnivorous species of Hydrophilidae, Staphylinidae, Oxytelinae and Scarabaeidae (in addition to beetles, representatives of many fly families live in dung; e.g. Haarto et al. 2002). Hence, the number of species in the communities was considerable. After a thorough niche analysis, they suggested that the patchy distribution and transient occurrence of suitable microhabitats contribute to the coexistence of many ecologically similar species. Considering all insects, Hanski (1987) listed a total 250 species belonging to 21 families or subfamilies in the fauna of dung in a typical south Finnish pasture; Roslin et al. (2014) added some tens of species in 15 families.

Dung beetles, 51 species in the superfamily Scarabaeoidea in Finland (Roslin et al. 2014), were studied in more detail. Dung beetles thrived well in former kind of pastures which were abundant in Finland still for half a century ago, but then the intensification and more recent industrialisation of farming is reflected also in the abundance and distribution of dung beetles: 25 of the species are threatened or near threatened (I. Hanski in Roslin and Heliövaara 2007, Roslin et al. 2014, Malmberg et al. 2019). According to Hanski, the abundance and species number of dung beetles naturally indicate not only the number of dung producers, but also on what kind of pastures animals are held.

First quantitative studies of dung-inhabiting beetles in Finland were done by Rainio (1966). He studied scarabeid, histerid, Sphaeridium, and silphid beetles from equal-weight dung heaps which he had placed in field and 


\section{AGRICULTURAL AND FOOD SCIENCE}

J. Tiainen et al. (2020) 29: 68-97

collected the beetles from them at 10-day intervals. The analysis revealed that, among other things, the nature (cow, horse, sheep, and pig dung) of dung and shadiness of the pasture affected the beetle abundance. Several species preferred or avoided certain kind of dung. However, Hanski and Kuusela (1983) found that cow and sheep dung communities of Aphodius show a difference in their abundance relations (less evenly distributed in sheep dung), but the difference is smaller in areas where the two types of community are in close proximity, and frequent between-community movements are possible. The number of species Rainio (1966) found in his study area was 22 for scarabeids, 5 histerids, 5 silphids and 3 hydrophilids.

Some traits which make Fennoscandian dung beetles sensitive to environmental change will also render them functionally efficient, their functional and response traits (body size and nesting strategy either as dwellers or tunnelers) being linked (Piccini et al. 2018). Among these dung beetle species, $75 \%$ of tunnelers and $30 \%$ of dwellers are classified as threatened. Nesting strategy significantly affects the probability of a species being threatened and constitutes a response trait. Effect traits varied with the ecological function investigated: density-dependent dung removal was influenced by both nesting strategy and body mass, whereas methane emissions varied with body mass and nutrient cycling with nesting strategy. Thus, the findings of Piccini et al. (2018) suggest that among Scandinavian dung beetles, nesting strategy is both a response and an effect trait, with tunnellers being more efficient in providing several ecological functions and also being more sensitive to extinction.

Roslin et al. (2014) regarded changes in cattle farming practices as the most important threat to many Nordic dung beetle populations. In particular, the decline in grazing of pastures on warm, meagre, dry and/or sandy soils seems a prime concern for many specialized species. The decline in the general density of pastures also likely contributes to the decline of many small and weakly dispersive species, along with antiparasitic treatment and a general shortening of the grazing period.

\section{Pollinators}

Leys are mainly grown for grass production, and their main species are wind-polluted graminids. If dicot plants also grow in leys, many groups of insect pollinators are present. These include, among others, honeybees Apis mellifera, bumblebees Bombus spp., cuckoo bumblebees Psithyrus spp., and butterflies. In local bumblebee communities, the number of species seems be related to proboscis length of foraging individuals and corolla tube depth of flowering resource plants (Ranta and Vepsäläinen 1981). Thus, Ranta and Tiainen (1982) found that when the structure of bumblebee communities of meadow-like abandoned fields was expressed in terms of diversity of proboscis lengths and corolla tube depths, a positive correlation was found. Thus, their results suggested that species with similar proboscis tend to co-occur on fields with availability of appropriate corolla tubes. Hence, the diversity of flowering dicot vegetation leads to larger local bumblebee diversity.

Bumblebee species richness and abundance was studied in leys with red clover Trifolium pratense at the South Savo Experimental Station of Agricultural Research Centre in Mikkeli in the 1960s and 1970s (Valle et al. 1960, 1964, Mela 1969, Teräs 1976a). The interest in bumblebees was due to their role in pollinating the red clover and thus their impact on seed production; such studies had been made already since the 1930s (Valle 1955, for literature, see Teräs 1976a). No other studies have been carried out in leys in Finland, but numerous related studies in field margins, buffer zones, set-asides and environmental fallows were conducted since the late 1990s (Bäckman and Tiainen 2002, Teräs 1976b, Toivonen et al. 2015, 2016). These studies provide a valuable basis for assessment of the biodiversity capacity of grass under different management regimes.

In Mikkeli, Teräs (1976a) observed eleven species of bumblebees during 1972-1974, the most common of which were $B$. lucorum, B. pascuorum, and B. hortorum. The annual abundance varied much, and it was generally lower than Valle et al. (1964) and Mela (1969) found in the same area in the 1960s. In contrast to bumblebees, honeybees did not play a role in clover pollination in Karila. An increase in the number of different dicot food plants increased the abundance of less numerous bumblebee species (Teräs 1976a, 1985). The abundance of bumblebees was higher near the field edge than in the centre of the field (Teräs 1976a). Teräs (1976b) also followed bumblebees' (and cuckoo bumblebees') flower visits during one summer on an uncultivated field. He found 59 species of nectar providing flowering plant species. The most visited ones were Salix spp. in May, Geum rivale, Vicia sepium and Rubus idaeus in June, Vicia cracca and Trifolium pratense in July and early August, and Solidago virgaurea at the end of August. Different species visited different flower species, their choice mainly depending on the depth of the corolla tube and length of tongue. Male bumblebees and cuckoo bumblebees preferred tall composites.

Already Teräs $(1976 a, 1985)$ found that field margins are used by a higher number of bumblebee species than the field itself because the dicotyledonous plant species richness is higher there. Bäckman and Tiainen (2002) 


\section{AGRICULTURAL AND FOOD SCIENCE}

J. Tiainen et al. (2020) 29: 68-97

conducted an extensive bumblebee and cuckoo bumblebee census in field margins in the agricultural environments in Lammi in relation to habitat availability and quality of field margins. They found a total of 15 species and that the expected number of species for a sample of 200 counted individuals varied from some 6 to the maximal 15. Species richness and total density were higher in farmland areas where field margins had more dicot flowers rather than being grassy. Abundance and flowering phenology of a limited number of flower species during the bumblebee breeding season were the most important factors explaining bumblebee visits in field margins. The most important flower species was Trifolium medium. The width of field margins was significantly related to the total density of bumblebees and cuckoo bumblebees, but not species number or diversity.

Ekroos et al. (2008) studied how field boundary habitat quality and farming system (organic or conventional) affect species richness and abundance of bumblebees and diurnal lepidopterans. The results showed positive effects of field boundary area on lepidopteran diversity, as well as positive effects of nectar flower abundance on the abundance of both groups. Organic farming did not show any significant effect on lepidopteran diversity, but bumblebee diversity tended to be higher at organic plots, which suggests that these important pollinators are able to react on even small changes in habitat quality of cultivated lands. Pöyry et al. (2009) found that habitat quality and, for declining butterflies and moths, well-connected networks of semi-natural grasslands explained better species richness and total abundance than habitat patch size.

Traditional grazing and mowing have been important factors in both the creation and maintenance of semi-natural grasslands of high floral and faunal diversity (e.g. Pykälä 2001, Saarinen and Jantunen 2005, Pöyry 2007). Different butterfly and moth species are dependent on various vegetation heights and temperature condition and, therefore, their community diversity is favoured by varying modes of management (Pöyry et al. 2004, 2005, $2006,2009)$. Saarinen $(2002 a, b)$ found that species diversity of butterfly communities was smaller in grazed than semi-natural grasslands because there was less nectar producing plants in the former ones. Saarinen and Jantunen $(2002,2005)$ studied the ecological impact of mowing and grazing on grassland butterflies in eight mown and eight grazed pastures under traditional animal husbandry in Northwest Russia and adjacent Finland. They found the total of 48 butterfly species in 1997-1999 and that the fauna was rather similar under both management regimes. Species richness and diversity, and total abundance did not significantly differ between meadows and pastures, yet meadows were preferred by more species. Results from an ordination analysis were interpreted to show that butterfly communities were affected more by the origin and age of the grassland than the present management methods. Surrounding landscape, the abundance of nectar plants and the intensity of tilling were the most important factors differentiating older grasslands from the younger ones evolved from old Finnish hay fields cultivated prior to the 1940s. In addition, Pöyry (2007) working on restoration of semi-natural grasslands, found that highest species richness and peak abundance of most individual species of butterflies and moths were observed in relatively tall grassland vegetation suggesting that less intensive management is preferred in order to maintain biodiversity of butterflies. He also concluded that the ecological requirement of all species and species groups are probably never met at a one site and consequently target should be in having differently managed areas at regional scale (Pöyry 2007, see also Johansen et al. 2019).

Toivonen et al. $(2015,2016)$ experimentally studied pollinator communities in different landscape contexts on environmental fallows established with different meadow plant seed mixtures. They found that bumblebees were most abundant in early successional stages with many nectar providing flower plant species whereas butterflies benefitted from long-term grassland fallows. The results showed that diversity of both butterflies and bumblebees can be enhanced both in open and forest-dominated landscapes. For conservation of habitat specialists and less mobile species they found that retention of long-term fallows is apparently a good option in grassland-rich landscapes.

\section{Soil biota}

Soil biodiversity is crucial for grass cultivation and the whole agricultural ecosystem due to ecosystem services it provides (e.g. nutrient cycling, soil structure and water regulation). Soil biota consists of fauna (e.g. earthworms and springtails) and microbial community (bacteria, fungi and archaea). We were able to find only a few Finnish scientific papers focusing on below-ground biota in various agroecosystems including pastures, and none about the effects of intensive silage cultivation on biodiversity of below-ground soil organisms. In Sweden, Persson \& Lohm (1977) made a more comprehensive assessment of the abundance, biomass and respiratory metabolism for about 250 species living in an abandoned field. Lagerlöf et al. (2002) studied the earthworm (Lumbricidae) community in a cereal field, surrounding field boundaries (640 $\mathrm{m}$ long) and a pasture adjoining to the field near Uppsala, Central Sweden. Their expectation was that the abundance and biomass of earthworms would have been larger in field boundaries and the pasture, but in fact these increased towards 


\section{AGRICULTURAL AND FOOD SCIENCE}

J. Tiainen et al. (2020) 29: 68-97

the centre of the field. They suggested, however, that situations can occur when the earthworm populations in the field decline, and the boundaries may serve as sources from where re-immigration can take place. Nieminen et al. (2011) found that grazed pastures had more than three times higher earthworm biomass than non-grazed agricultural fields. In addition, Mikola et al. (2009) found that among soil fauna, grazing increased the abundance of Aporrectodea earthworms and fungivorous nematodes living and feeding in rhitzosphere, i.e. grazing increases root defoliation and thus more food is available for root feeders. In contrast, the abundance of detritivorous enchytraeids and Lumbricus earthworms feeding mostly decayed litter on soil surface decreased, i.e. food availability for litter feeders was reduced because less litter ends on soil surface in grazed pastures. However, the mechanisms were more mixed, with effects explained by defoliation, patchy excreta return, and cow trampling. Microbial-feeding nematodes, enchytraeids and earthworms did not appear to benefit from the dung and urine addition. Mikola et al. (2009) concluded that spatial distribution of resource return has a significant role in determining the effects on soil organisms in pastures. In Finland, overgrazing is not common in large scale on pastures except on animal concentration areas like water points although trampling is shown to compact soil during grazing years in Finland, too (Saarijärvi 2008, Mikola et al. 2009).

In addition, we found two reports comparing the abundance of earthworms in organic and conventionally farmed fields in Finland. Palojärvi et al. (2002) found that there were no consistent differences in earthworm abundances of adjacent organic and conventional cropping systems. Nuutinen and Haukka (1990) did neither find clear differences in the earthworm species composition between organic and conventional cropping systems. They observed highest abundances of earthworms and their cocoons in organically cultivated vetch ley. However, data of previous studies did not allow differentiation between meadows and conventionally tilled soils.

Hokkanen et al. (2006c) studied the nematodes in meadows, birch forests and mixed forests in Tohmajärvi, North Karelia each treatment having three plot pairs with grazing and non-grazing in 1995 and 2006. Number of nematode genera was quite similar between the sites but, as expected, the nematode community composition of the meadow differed from that of near forest pastures. The nematode community in meadow comprised 70 taxa which belonged to 53 genera. Six of the genera (Plectus, Rhabditis, Eucephalobus, Chiloplacus, Eudorylaimus, Pratylenchus) were found in all meadow samples. In meadows, higher nematode abundance and biomass were found in non-gazed areas. The proportion of bacterial feeders increased in grazed areas. However, heterogeneity of study sites and inconsistency in the results among the pairs makes further conclusions difficult.

Studies regarding other organisms of grassland soil fauna are almost missing in Finland. Komonen and Kataja-aho (2017) studied springtails (Collembola) in meadows, pastures and road verges in Central Finland. The number of species was higher in meadows and road verges ( 40 and 39 species, respectively) than in pastures (33 species) but unfortunately their data were too small for statistical comparisons. The somewhat smaller species number in pastures may result from animals trampling on pitfall traps, which was commonly observed, or soil compaction (Komonen and Kataja-aho 2017). Törmälä (1979) estimated the biomass proportions of soil fauna (excluding Protozoa, Tardigrada and Rotatoria) and found that, in July, of the $9.6 \mathrm{~g}$ dry weight $\mathrm{m}^{-2}$ Lumbricidae (73.1\%), Enchytraidae (5.7\%), Oribatei (5.0\%) and Nematoda (4.4\%) were the most dominant groups in a reserved field. In September, the biomass of dipteran larvae was $1.0 \mathrm{~g} \mathrm{dw} \mathrm{m}^{-2}$ in the same field.

In spite of the importance of microbes, quite little research has been carried out on Finnish arable soils. Some studies have focused on some specific microbial activity in grasslands. For example, Nykänen et al. (2008) studied the efficiency of nitrogen fixation of nitrogen-fixing bacteria in the root nodules of clover. Palojärvi et al. (2000) did not find consistent differences on soil quality properties between organic and conventional fields. However, microbial biomass nitrogen and basal respiration were higher under organic farming. Potentially, some specific measures like crop rotation with grass ley seemed to support soil biota, regardless of the management system. Thus, Manoharan et al. (2017) found that the functional genes of microbial communities had higher abundance and diversity of sequences coding for enzymes degrading soil organic matter in grasslands than in winter wheat soil.

Dung is a major input of nutrients and carbon into soil food web in livestock based agricultural systems. Slade et al. (2016b) studied the interaction of dung beetles and soil microbes in dung decomposition. They found that the microbial communities were distinct in soil and dung samples but converged over the course of their experiment. Thus, the interaction between dung beetles and microbial communities in dung and soil provides a link in biochemical cycling in agricultural systems. During this process, dung beetle communities modified some aspects of both microbial community structure and functioning both in the dung pats and in the soil underneath them. With these results, they suggested that the beetles may serve as mobile links between decomposition processes occurring above and below ground. The interaction between microbiota in dung and dung beetles, greenhouse 


\section{AGRICULTURAL AND FOOD SCIENCE}

J. Tiainen et al. (2020) 29: 68-97

gas fluxes from dung, and beetle size, survival and reproduction may be affected by antibiotic treatment of livestock. Indeed, Hammer et al. (2016) found that antibiotic treatment restricted microbiota in dung beetles, and, unexpectedly, also raised methane fluxes from dung, possibly by altering the interactions between methanogenic archaea and bacteria in rumen and dung environments. These cascading ecological effects that extend beyond the target animal are, however, not as severe and threatening in Finnish animal husbandry as in some other countries because antibiotics are not routinely used to improve livestock health and growth in Finland.

Regarding soil monitoring, the soil quality concept and its importance in the study of Finnish arable soils were reviewed by Palojärvi and Nuutinen (2002); the review includes chemical, physical and biological properties. However, the largest monitoring programme 'VALSE' on Finnish arable soils covers chemical indicators only (Heikkinen et al. 2013).

\section{Aquatic ecosystems}

Diffuse pollution from agriculture and forestry is the most notable stressor impairing the condition of surface waters in Finland. In farmland, field margins and shelter belts reduce nutrient load and erosion from fields with variable efficiency depending on the width of the verge, soil type and exposure (Puustinen et al. 2019). Agriculture alone has been estimated to cause $60 \%$ of phosphorus and $50 \%$ of nitrogen loading to inland waters being heaviest in southern and western parts of Finland (Nyroos et al. 2006).

Phosphorus is the limiting nutrient for eutrophication in inland waters in Finland (Niemi et al. 2004). In comparison with croplands, grasslands reduce erosion and, consequently, the transfer of particulate P from land to water, but the concentration of dissolved $P$ in surface runoff from grasslands can be high (Turtola and Kemppainen 1998). The P load from silage production has been shown to be clearly lower (Puustinen et al. 2019) whereas P load from pastures is similar (Järvenranta et al. 2014) to the Finnish reference value from agricultural production in general (1.1 kg P ha-1; Tattari et al. 2017). In contrast to P, N is leached mainly through the soil. Whereas leaching of mineral $\mathrm{N}$ is low, using slurry and organic $\mathrm{N}$ has increased $\mathrm{N}$ leaching risk from silage leys up to $11-54 \mathrm{~kg} \mathrm{ha}^{-1} \mathrm{year}^{-}$ ${ }^{1}$ (Räty et al. 2018). Buffer zones significantly reduce the nitrogen load from fields (Valkama et al. 2019).

Over the decades, impact assessment in Finland has focused on water quality, and very little knowledge exists on aquatic species or community level effects (e.g. fish, macroinvertebrates, macrophytes and phytoplankton) or ecosystem functioning (e.g. periphytic primary production). A recent study suggests, however, that agricultural diffuse pollution reduces the diversity of several lotic taxa, and even overwhelms the effects of hydromorphological modifications of channels (Turunen et al. 2016). However, the role of grass cultivation cannot be separated from the other agricultural nutrient load.

\section{Discussion}

As expected, our literature review revealed livestock production to have an impact on both taxonomic and functional biodiversity. However, the extent of information varied a lot among groups of organisms. Most information was available on plants, birds and some invertebrate groups and least information on below-ground soil biodiversity. The impact is mediated through intensification of land-use, grass cultivation or both, which both relate to continuation of former animal husbandry or abandonment of it. Intensive grass production is practiced in cattle farms and their neighbourhood whereas elsewhere grasslands are more or less extensively managed. In general, we found that the amount, quality, spatial distribution in different scales of grass habitats, both intensively cultivated and grazed, were important determinants of biodiversity, and that different populations even within a species group are favoured by different kind of management. From the biodiversity point of view, it is urgent to keep and as far possible increase diversity of different kind of grasslands in all spatial scales.

\section{Biodiversity}

The results demonstrated how biodiversity is affected adversely by the concentration of animal husbandry regionally and locally which results in uneven distribution of grasslands (Supplementary information: Table 1). Large parts of Finland in the south and west have very little animal husbandry left whereas mixed farms with dairy cattle were typical also here still in the 1960s after which a steep decline started. At the same time, the intensity of remaining grass production increased (Fig. 2). Livestock farms intensively produce grass, but they have also extensive grasslands. Other kind of farms do not cultivate grass intensively, and they may have 


\section{AGRICULTURAL AND FOOD SCIENCE}

J. Tiainen et al. (2020) 29: 68-97

hay fields to cultivate fodder for horse farms, or only extensive grasslands such as fallows, set-asides, field margins, shelter belts, buffer zones and possibly semi-natural grasslands. The extent of extensively managed grasslands is mostly unknown; such information is available only for fallows and set-asides whose amount is regulated with agricultural policy.

Our review demonstrated that quite much is known about biodiversity in extensively managed grasslands, but very little in intensively managed grasslands, especially silage and green fodder fields. As extensive grasslands provide habitat for a rich flora and fauna, their preservation is important. However, the whole spectrum of extensive grasslands is not well represented in agricultural context because most semi-natural habitat types are threatened and rare (Lehtomaa et al. 2018). Also the amount and impact of extensively managed grasslands is declining because there is a tendency to intensify land-use by unifying fields which destroys habitats and biodiversity because open ditches and margins are thereby removed (the strategy from 2014 for reallocation of pieces of land recognises all benefits but does not consider biodiversity impacts; MMM 2015). The amount of extensive grasslands was already declined when European Union reduced from the 10\% set-aside demand in 2007 and adopted the new greening policy with much smaller grass area demand. This provides a task for land use optimization and preservation of habitat mosaic at the farm level and between farms (Tiainen et al. 2004a, Landis 2017, Peltonen-Sainio et al. 2019).

The review shows convincingly how disappearance of cattle production has caused a decline of biodiversity in large areas of southern and western Finland. However, the decline of cattle production has not only caused biodiversity decreases, since a new community composition may have preserved diversity. Later biodiversity declines may have followed the decrease in the amount of low-intensity grasslands caused by landscape changes. Also, abandonment of traditional management of semi-natural grasslands has caused biodiversity losses (Pykälä 2001, 2007, Jantunen 2003a, b, Pöyry 2007). In these areas, other kind of extensive grasslands partially compensate the disappearance of semi-natural grasslands and pastures. Horses and sheep have nowadays again become more common in southern Finland, but their impact on local or regional biodiversity has not been studied.

The review revealed lacks in the knowledge of biodiversity in intensive grass production as such and especially in relation to arable farming which is the most likely alternative (production form) for many farms. Firstly, there is virtually almost no research on intensive grass fields but the few records of non-cultivated plant species (Suppl. Table 6). Secondly, milk production is increasingly concentrated in large units where the cattle are kept in large cowsheds from where they usually have the access only to small recreational pastures. Pastures support rich biological communities and ecological processes, and their biodiversity will suffer when grazing is abandoned. Thirdly, the number of dairy farms is decreasing in southern and western Finland and a large part of farms giving up with milk production switch to arable farming, mainly grain production. In eastern and northern Finland, also fields of farms abandoning cattle farming, if remaining and growing cattle farms can buy or hire them. There is a clear lack of direct estimation how these changes affect different aspects of biodiversity, perhaps except for birds and mammals. Moreover, the intensity of grass production tends to increase in growing cattle farms, but also the impact of this on biodiversity requires research.

An important question is whether there is some threshold for the proportion of grasslands under which regional biodiversity will be reduced. Answering this question would need also an assessment of species specialization to various grasslands. For many bird species, the landscape context, i.e. whether there are grasslands or not, is important. Also, half of dung inhabiting beetles have become threatened in lack of their resource. For many dung -inhabiting species or species groups, it has been found that their abundance and even prevalence is lowered when there are less grasslands, which has, however, usually been connected to the disappearance of cattle from the landscape (Roslin 2000, 2001, Roslin and Koivunen 2001, Roslin et al. 2014). The dung-inhabiting beetles are not able to use liquid manure and, hence, they cannot provide the ecosystem service which may have on effect on greenhouse gas emissions. For butterflies Ekroos et al. (2010a) found homogenization of the community in field margins or semi-natural meadows, probably as a result of declined availability of suitable breeding habitat. Not much information was available on responses of aquatic biodiversity. The grass cultivation effects are lumped with other forms of land use due to their mosaic structure in watersheds, but the effects are likely in the lower end of the scale.

\section{Ecosystem services}

Our literature review showed the information on ecosystem services provided by biodiversity to be limited. An extensive literature review into the ecosystem services provided by field margins showed that field margin and non-crop vegetation around agricultural lands can provide various benefits including pest control, crop pollina- 


\section{AGRICULTURAL AND FOOD SCIENCE}

J. Tiainen et al. (2020) 29: 68-97

tion, reduced offsite erosion, organic matter decomposition and nutrient cycling as well as enhancement of rare and endangered species, both above and below ground organisms (Mkenda et al. 2019: 18). The significance of biodiversity should be understood through ecosystem functioning, services and resilience, but the quantitative relationship between them is still poorly understood (see de Groot et al. 2016). In general, models and studies have shown that increasing species richness enhances the maintenance of several ecosystem processes (Quijas and Balvanera 2013). Structurally complex agricultural landscapes allow for the maintenance of biodiversity that is expected to contribute to the maintenance of various ecosystem services (Tscharntke et al. 2005). Grassland biodiversity provides important ecosystem services, such as natural pest control (birds, invertebrates), alternative and overwintering habitat for invertebrate predators, food and alternative habitat for pollinators, dung composting, carbon accumulation, nutrient recycling in soil, and absorbing nutrients and solid mineral particles from surface waters. Nowadays, farmers are increasingly aware on their dependence of ecosystem services provided by biota, especially in organic farming (Eyre et al. 2013, Tscharntke et al. 2016).

Regarding climate change, the relationship of biodiversity and GHG fluxes and sequestration of carbon into earth is recognized but its quantitative significance needs still deeper understanding. Several recent papers suggest also that dung beetles may affect the fluxes of GHGs from cattle farming. Piccini et al. (2017, see also Penttilä et al. 2013, Slade et al. 2017) found that the overall presence of dung-inhabiting beetles significantly affected the GHG fluxes, but different species contributed unequally to the emissions. With three common dung beetle species, dung proved to emit less gases than did beetle-free dung, the reduction being $-32 \%$. The fourth species in the experiment, a large tunneler (Copris lunaris), provided a disservice, as it significantly increased the $\mathrm{CH}_{4}$ flux.

Maljanen et al. (2012) and Slade et al. (2016a) put previous findings into context. Maljanen et al. (2012) found that $\mathrm{CH}_{4}$ emission from pastures in Central Finland was low and only $0.2 \%$ of annual emission of a dairy cow. In addition, Slade et al. (2016a), using Finland as an example, assessed GHG emissions at three scales: the dung pat, pasture ecosystem, and whole lifecycle of milk or beef production. They found that at the first two scales, dung beetles reduced emission by up to $7 \%$ and $12 \%$, respectively, mainly through large reductions in methane emissions. However, at the lifecycle level, dung beetles accounted for only a $0.05-0.13 \%$ reduction of overall GHG emissions. They explained the mismatch from the fact that in intensive production systems, only a limited fraction of all cow dung ends up as pats on pastures, offering a limited scope for dung beetle mitigation of GHG fluxes.

Kaartinen et al. (2013) estimated that an average fraction of $68 \%$ of the original cow dung disappears due to evaporation and microbial activity. Another $13 \%$ disappears due to invertebrate activity, whereas $10 \%$ remains by the end of the season in southernmost Finland, but $26 \%$ in Lapland. Of the dung decomposed by invertebrates, dor beetles Geotrupes spp. accounted for $61 \%$, earthworms $28 \%$ and Aphodius dung dwellers for $11 \%$. One third of the amount decomposed by dor beetles was buried under the cow pat, and about two-thirds were consumed.

Even if below ground soil fauna and microbial community has a high redundancy i.e. saturation of function at low levels of species richness, the research on soil organism biodiversity and its function is not irrelevant (Wolters 2001). In fact, the Soil Thematic Strategy (Commission of the European Communities 2002) highlighted the soil biodiversity as a key component of soil quality. For example, several soil fauna and micro-organisms, in association with plant roots, ensure plant litter degradation, carbon sequestration, nutrient cycling, participate on pest and disease control in soil and consequently, also on greenhouse gas emissions. In addition, soil structure and water infiltration in the soil are largely controlled by soil fauna, especially earthworms, and soil micro-organisms. These services are not only critical to the functioning of natural ecosystems but are also important for sustainable agricultural production and mitigation of climate change (Pulleman et al. 2012, Creamer et al. 2016, Plantureux et al. 2016). The functioning soil fauna and microbial community are essential also for maintenance of water quality in aquatic systems of agricultural landscapes (Brussaard 1997).

\section{Conclusions and prospects}

Livestock production is important for biodiversity, the impact depending on production intensity. Information regarding different groups of organisms and management intensities varies a lot. Least information is available on soil biodiversity, which supports important ecosystem services, such as carbon sequestration and nutrient cycling. This information would be crucial for understanding the role of agricultural soil biodiversity in the prevention of climate change. A future challenge will be how to maintain the biodiversity supported by livestock production since there are demands for decreasing production due to its large role on ecosystems degradation and climate change. 


\section{AGRICULTURAL AND FOOD SCIENCE}

J. Tiainen et al. (2020) 29: 68-97

Intensive production offers limited value to replace the high biodiversity value of semi-natural pastures. However, in developing the production systems by adding biodiversity as one target there are some possibilities for improvement. This topic is currently gaining more attention in Europe, especially among those EU countries where agricultural land and grassland covers a large proportion of the land area. Crop rotations, crop species mixtures and permanent soil cover crops are techniques used to increase yield stability and soil fertility. These also have positive effects on biodiversity in general on both local (landscape or farm) and regional level. In addition, the introduction of grazing animals in farming cycles helps to retain biodiversity. The conservation and enhancement of biodiversity in cropping systems both above and below ground are prerequisites for sustainable farming. As a consequence, biodiversity is also improved in other parts of the environment, such as aquatic systems.

It is clear that more research is needed in developing intensive dairy systems that incorporate specific measures to improve biodiversity in the Finnish context. More research is also needed into the interacting roles of intensive grass and other agricultural production and biodiversity for producing ecosystem services, such as integrating above- and below-ground ecosystem functions better into agricultural practices, carbon sequestration and prevention of GHG emissions.

\section{Acknowledgements}

We express our sincere thanks to two reviewers whose comments on the manuscript were beneficial. This review was implemented as a customer project funded by Valio Oy and A-Tuottajat Oy. JT was responsible for the final shape of the review. All members of the team participated in planning and writing the review. The contributions of writers were as follows: Introduction: JT, TH, PV, PT. The farm ecosystem and grass production: JT, TH, AM. Vascular plants: JT, TH, PV. Mammals: JT. Birds: JT, TS. Invertebrate fauna: JT. Predatory invertebrates: EH-V, JT. Dung-inhabiting beetles: JT. Pollinators: JT. Soil: MH, AP. Aquatic ecosystems, indirect effects of nutrients: PL, TMN, PV. Discussion: All authors.

The work of JT and TS was a part of the project Optimising Agricultural Land Use to Mitigate Climate Change (OPALLife, LIFE14 CCM/FI/000254; this paper reflects only the authors' views and the EASME/Commission is not responsible for any use that may be made of the information it contains). JT acknowledges also the Lammi Biological Station (University of Helsinki) which provided excellent working opportunities during 1984-2013 for much of his biodiversity work reviewed in this paper.

\section{References}

Allan, E., Bossdorf, O., Dormann, C.F., Prati, D., Gossner, M.M., Tscharntke, T., Blüthgen, N., Bellach, M., Birkhofer, K., Boch, S., Böhm, S., Börschig, C., Chatzinotas, A., Christ, S., Daniel, R., Diekötter, T., Fischer, C., Friedl, T., Glaser, K., Hallmann, C., Hodac, L., Hölzel, N., Jung, K., Klein, A.M., Klaus, V.H., Kleinebecker, T., Krauss, J., Lange, M., Morris, K.E., Müller, J., Nacke, H., Pasalic, E., Rillig, M.C., Rothenwöhrer, C., Schall, P., Scherber, C., Schulze, W., Socher, S.A., Steckel, J., Steffan-Dewenter, I., Türke, M., Weiner, C.N., Werner, M., Westphal, C., Wolters, V., Wubet, T., Gockel, S., Gorke, M., Hemp, A., Renner, S.C., Schöning, I., Pfeiffer, S., KönigRies, B., Buscot, F., Linsenmair, K.E., Schulze, E. D., Weisser, W.W. \& Fischer, M. 2014. Interannual variation in land-use intensity enhances grassland multidiversity. PNAS 111: 308-313. https://doi.org/10.1073/pnas.1312213111

Allen, V.G., Batello, C., Berretta, E.J., Hodgson, J., Kothmann, M., Li, X., Mclvor, J., Milne, J., Morres, C., Peeters, A. \& Sanderson, M. 2011. An international terminology for grazing lands and grazing animals. Grass and Forage Science 66: 2-28. https://doi.org/10.1111/j.1365-2494.2010.00780.x

Bäckman, J.-P.C. \& Tiainen, J. 2002. Habitat quality of field margins in a Finnish farmland area for bumblebees (Hymenoptera: Bombus and Psithyrus). Agriculture, Ecosystems and Environment 89: 53-68. https://doi.org/10.1016/S0167-8809(01)00318-8

Berg, L., Itämies, J. \& Kuusela, K. 1978. On the succession of the vegetation of hay fallows (reserved fields) in northern Finland. Luonnon Tutkija 82: 48-49. (in Finnish).

Birkhofer, K., Bezemer, T.M., Bloem, J., Bonkowski, M., Christensen, S., Dubois, D., Ekelund, F., Fließbach, A., Gunstg, L., Hedlund, K., Mäder, P., Mikola, J., Robin, C., Setälä, H., Tatin-Froux, F., van der Putten, W.H. \& Scheu, S. 2008. Long-term organic farming fosters below and aboveground biota: implications for soil quality, biological control and productivity. Soil Biology and Biochemistry 40: 2297-2308. https://doi.org/10.1016/j.soilbio.2008.05.007

Blüthgen, N., Dormann, C.F., Prati, D., Klaus, V.H., Kleinebecker, T., Hölzel, N., Alt, F., Boch, S., Gockel, S., Hemp, A., Müller, J., Nieschulze, J., Renner, S.C., Schöning, I., Schumacher, U., Socher, S.A., Wells, K., Birkhofer, K., Buscot, F., Oelmann, Y., Rothenwöhrer, C., Scherber, C., Tscharntke, T., Weiner, C.N., Fischer, M., Kalko, E.K.V., Linsenmair, K.E., Schulze, E.-D. \& Weisser, W.W. 2012. A quantitative index of land-use intensity in grasslands: integrating mowing, grazing and fertilization. Basic and Applied Ecology 13: 207-220. https://doi.org/10.1016/j.baae.2012.04.001

Brussaard, L. 1997. Biodiversity and ecosystem functioning in soil. Ambio 26: 563-570.

Cederlund, G. \& Liberg, O. 1995. Rådjuret. Viltet, ekologin och jakten. Svenska Jägareförbundet, Uppsala. 301 p. (in Swedish). 
Commission of the European Communities 2002. Towards a thematic strategy for soil protection. Communication from the Commission to the Council, the European Parliament, the Economic and Social Committee and the Committee of the Regions. COM (2002) 179 final, Brussels. 35 p. https://eur-lex.europa.eu/legal-content/EN/TXT/PDF/?uri=CELEX:52002DC0179\&from=EN

Creamer, R.E., Hannula, S.E., Van Leeuwen, J.P., Stone, D., Rutgers, M., Schmelz, R.M., de Ruiter, P.C., Hendriksen, N.B., Bolger, T., Bouffaud, M.L., Buee, M., Carvalho, F., Costa, D., Dirilgen, T., Francisco, R., Griffiths, B.S., Griffiths, R., Martin, F., Martins da Silva, P., Mendes, S., Morais, P.V., Pereira, C., Philippot, L., Plassart, P., Redecker, D., Römbke, J., Sousa, J.P., Wouterse, M. \& Lemanceau, P. 2016. Ecological network analysis reveals the inter-connection between soil biodiversity and ecosystem function as affected by land use across Europe. Applied Soil Ecology 97: 112-124. https://doi.org/10.1016/j.apsoil.2015.08.006

de Groot, R., Jax, K. \& Harrison, P. 2016. Links between biodiversity and ecosystem services. In: Potschin, M. \& Jax, K. (eds.). OpenNESS ecosystem services reference book. EC FP7 Grant Agreement no. 308428.

http://www.openness-project.eu/sites/default/files/SP_Link_between_biodiversity_and_ecosystem_services.pdf

de Jong, A. 2012. Seasonal shift of foraging habitat among farmland breeding Eurasian curlews Numenius arquata. Ornis Norvegica 35: 23-27. https://doi.org/10.15845/on.v35i0.237

Díaz, S., Settelem, J., Brondízio, E.S., Ngo, H.T., Guèze, M., Agard, J., Arneth, A., Balvanera, P., Brauman, K.A., Butchart, S.H.M. Chan, K.M.A., Garibaldi, L.A., Ichii, K., Liu, J., Subramanian, S.M., Midgley, G.F., Miloslavich, P., Molnár, Z., Obura, D., Pfaff, A., Polasky, S., Purvis, A., Razzaque, J., Reyers, B., Chowdhury, R.R., Shin, Y.J., Visseren-Hamakers, I.J., Willis, K.J. \& Zayas, C.N. (eds.) 2019. Summary for policymakers of the global assessment report on biodiversity and ecosystem services of the Intergovernmental Science-Policy Platform on Biodiversity and Ecosystem Services. IPBES secretariat, Bonn, Germany. 56 p. https://doi.org/10.5281/ zenodo.3553579

Eccard, J.A. \& Ylönen, H. 2002. Direct interference or indirect exploitation? An experimental study of fitness costs of interspecific competition in voles. Oikos 99: 580-590. https://doi.org/10.1034/j.1600-0706.2002.11833.x

Ekroos, J., Heliölä, J. \& Kuussaari, M. 2010a. Homogenization of lepidopteran communities in intensively cultivated agricultural landscapes. Journal of Applied Ecology 47: 459-467. https://doi.org/10.1111/j.1365-2664.2009.01767.x

Ekroos, J., Hyvönen, T., Tiainen, J. \& Tiira, M. 2010b. Responses in plant and carabid communities to farming practices in boreal landscapes. Agriculture, Ecosystems and Environment 135: 288-293. https://doi.org/10.1016/j.agee.2009.10.007

Ekroos, J., Kuussaari, M., Tiainen, J., Heliölä, J., Seimola, T. \& Helenius, J. 2013. Correlations in species richness between taxa depend on habitat, scale and landscape context. Ecological Indicators 34: 528-535. https://doi.org/10.1016/j.ecolind.2013.06.015

Ekroos, J., Piha, M. \& Tiainen, J. 2008. Role of organic and conventional field boundaries on boreal bumblebees and butterflies. Agriculture, Ecosystems and Environment 124: 155-159. https://doi.org/10.1016/j.agee.2007.09.003

Ekroos, J., Tiainen, J., Seimola, T. \& Herzon, I. 2019. Weak effects of farming practices corresponding to agricultural greening measures on farmland bird diversity in boreal landscapes. Landscape Ecology 34: 389-402. https://doi.org/10.1007/s10980-019-00779-x

Elsässer, M. 2004. Problemunkräuter gezielt angehen. Grünlandpraxis für Profis. DLZ. Agrarmagazin, Sonderheft 12: 44-45.

Ergon, Å., Kirwan, L., Bleken, M.A., Skjelvåg, O.A., Collins, R.P. \& Rognli, O.A. 2016. Species interactions in a grassland mixture under low nitrogen fertilization and two cutting frequencies. 1. dry-matter yield and dynamics of species composition. Grass and Forage Science 71: 667-682. https://doi.org/10.1111/gfs.12250

European Union 2018. Land cover and land use. DG Agriculture and Rural Development, Unit Farm Economics. https://ec.europa.eu/agriculture/sites/agriculture/files/statistics/facts-figures/land-cover-use.pdf

Eyre, M.D., Luff, M.L. \& Leifert, C. 2013. Crop, field boundary, productivity and disturbance influences on ground beetles (Coleoptera, Carabidae) in the agroecosystem. Agriculture, Ecosystems and Environment 165: 60-67. https://doi.org/10.1016/j.agee.2012.12.009

Fan, F., Henriksen, C.B. \& Porter, J. 2018. Long-term effects of conversion to organic farming on ecosystem services - a model simulation case study and on-farm case study in Denmark. Agroecology and Sustainable Food Systems 42: 504-529. https://doi.org/10.1080/21683565.2017.1372840

Finn, J.A., Kirwan, L., Connolly, J., Sebastià, T.M., Helgadottir, A., Baadshaug, O.H., Bélanger, G., Black, A., Brophy, C., Collins, R.P., Čop, J., Dalmannsdóttir, S., Delgado, I., Elgersma, A., Fothergill, M., Frankow-Lindberg, B.E., Ghesquiere, A., Golinska, B., Golinski, P., Grieu, P., Gustavsson, A.-M., Höglind, M. Huguenin-Elie, O., Jørgensen, M., Kadziuliene, Z., Kurki, P., Llurba, R., Lunnan, T., Porqueddu, C., Suter, M., Thumm, U. \& Lüscher, A. 2013. Ecosystem function enhanced by combining four functional types of plant species in intensively managed grassland mixtures: a 3-year continental-scale field experiment. Journal of Applied Ecology 50: 365-375. https://doi.org/10.1111/1365-2664.12041

Frylestam, B. 1980. Utilization of farmland habitats by European hares (Lepus europaeus Pallas) in southern Sweden. Swedish Wildlife Research 11: 271-284. (in Swedish).

Frylestam, B. 1986. Agricultural land use effects on the winter diet of Brown Hares (Lepus europaeus Pallas) in southern Sweden. Mammal Review 16: 157-161. https://doi.org/10.1111/j.1365-2907.1986.tb00037.x

Frylestam, B. 1990. Lär känna fältharen. Svenska Jägareförbundet, Helsingborg. 45 p. (in Swedish).

Geiger, F., Bengtsson, J., Berendse, F., Weisser, W.W., Emmerson, M., Morales, M.B., Ceryngier, P., Liira, J., Tscharntke, T., Winqvist, C., Eggers, S., Bommarco, R., Pärt, T., Bretagnolle, V., Plantegenest, M., Clement, L.W., Dennis, C., Palmer, C., Oñate, J.J., Guerrero, I., Hawro, V., Aavik, T., Thies, C., Flohre, A., Hänke, S., Fisher, C., Goedhart, P.W. \& Inchausti, P. 2010. Persistent negative effects of pesticides on biodiversity and biological control potential on European farmland. Basic and Applied Ecology 11: 97-105. https://doi.org/10.1016/j.baae.2009.12.001

Gilbert, S., Norrdahl, K., Tuomisto, H., Söderman, G., Rinne, V. \& Huusela-Veistola, E. 2015. Reverse influence of riparian buffer width on herbivorous and predatory Hemiptera. Journal of Applied Entomology 139: 539-552. https://doi.org/10.1111/jen.12166 
Gossner, M.M., Lewinsohn, T., Kahl, T., Grassein, F., Boch, S., Prati, D., Birkhofer, K., Renner, S.C., Sikorski, J., Wubet, T., Arndt, H., Baumgartner, V., Blaser, S., Blüthgen, N., Börschig, C., Buscot, F., Diekötter, T., Jorge, L.R., Jung, K., Keyel, A.C., Klein, A.-M., Klemmer, S., Krauss, J., Lange, M., Müller, J., Overmann, J., Pašalić, E., Penone, C., Perović, D.J., Purschke, O., Schall, P., Socher, S.A., Sonnemann, I., Tschapka, M., Tscharntke, T., Türke, M., Venter, P.C., Weiner, C.N., Werner, M., Wolters, V., Wurst, S., Westphal, C., Fischer, M., Weisser, W.W. \& Allan, E. 2016. Land-use intensification causes multitrophic homogenization of grassland communities. Nature 540: 266-269. https://doi.org/10.1038/nature20575

Haarto, A., Mukkala, V.-M. \& Koponen, S. 2002. Tutkimus Rekijokilaakson hyönteisistä ja hämähäkkieläimistä. Lounais-Suomen ympäristökeskuksen monistesarja 5/2002. 58 p. (in Finnish). Håkansson, S. 2003. Weeds and weed management on arable land: an ecological approach. CABI Publishing. 274 p. https://doi.org/10.1079/9780851996516.0000

Hägg, M., Degerman, A., Pessa, J. \& Kovanen, T. 2006. Erilaisten hoitomenetelmien ja -käytäntöjen vaikutus Perämeren rantaniittyjen kasvillisuuteen ja maisemaan. In: Huuskonen, A. (ed.). LUMOLAIDUN: Maisemalaiduntaminen luonnon monimuotoisuuden lisääjänä - tasapaino monimuotoisuuden ja tuottavuuden välillä. Maa- ja elintarviketalous 79: 17-65. (in Finnish). http://urn.fi/URN:ISBN:952-487-031-2

Håkansson, S. 2003. Weeds and weed management on arable land: an ecological approach. CABI Publishing. 274 p. https://doi.org/10.1079/9780851996516.0000

Halmeenpää, R., Itämies, J. \& Välimäki, P. 2006. Metsälaidunnuksen vaikutukset maakiitäjäisten (Coleoptera: Carabidae) ja juoksuhämähäkkien (Araneae: Lycosidae) yhteisörakenteeseen Taivalkoskella. In: Huuskonen, A. (ed.). LUMOLAIDUN: Maisemalaiduntaminen luonnon monimuotoisuuden lisääjänä - tasapaino monimuotoisuuden ja tuottavuuden välillä. Maa- ja elintarviketalous 79: 346-375. (in Finnish). http://urn.fi/URN:ISBN:952-487-031-2

Hämet-Ahti, L., Suominen, J., Ulvinen T. \& Uotila, P. 1998. Field flora of Finland. Finnish Museum of Natural History, Botanical Museum. Helsinki. 656 p. (in Finnish).

Hammer, T.J., Fierer, N., Hardwick, B., Simojoki, A., Slade, E., Taponen, J., Viljanen, H. \& Roslin, T. 2016. Treating cattle with antibiotics affects greenhouse gas emissions, and microbiota in dung and dung beetles. Proceedings of the Royal Society B 283 : 20160150. https://doi.org/10.1098/rspb.2016.0150

Hanski, I. 1987. Nutritional ecology of dung- and carrion-feeding insects. In: Slansky, F. Jr. \& Rodrigues, J.G. (eds.). Nutritional ecology of insects, mites and spiders. John Wiley \& Sons, New York. p. 837-884.

Hanski, I. \& Cambefort, Y. 1991. Dung beetle ecology. Princeton Univ. Press, New Jersey. 520 p. https://doi.org/10.1515/9781400862092

Hanski, I. \& Koskela, H. 1977. Niche relations among dung-inhabiting beetles. Oecologia (Berl.) 28: 203-231. https://doi.org/10.1007/BF00751601

Hanski, I. \& Koskela, H. 1978. Stability, abundance, and niche width in the beetle community inhabiting cow dung. Oikos 31: 290298. https://doi.org/10.2307/3543653

Hanski, I. \& Kuusela, S. 1983. Dung beetle communities in the Åland archipelago. Acta Entomologica Fennica 42: 36-42.

Hansson, L. 1977. Spatial dynamics of field voles Microtus agrestis in heterogenous landscapes. Oikos 29: 539-544. https://doi.org/10.2307/3543592

Hansson, L. \& Myllymäki, A. 1973. Förslag till standardisering av biotopparametrar vid smådäggdjurundersökningar. Nordmus Rapport 4: 20-29. (in Swedish).

Haugland, E. 1995. Rumex longifolius DC., Ranunculus repens L. and Taraxacum officinale (Web) Marss. in grassland. 2. Crop nutritive value in relation to proportion of dicots. Norwegian Journal of Agricultural Sciences 9: 85-93.

Heikkinen, J., Ketoja, E., Nuutinen, V. \& Regina, K. 2013. Declining trend of carbon in Finnish cropland soils in 1974-2009. Global Change Biology 19: 1456-1469. https://doi.org/10.1111/gcb.12137

Hellström, K. 2004. Variation in grazing tolerance and restoration of meadow plant communities. Ph.D. thesis, Acta Universitatis Ouluensis, Series A, Scientiae rerum naturalium 423, University of Oulu. 53 p. http://urn.fi/urn:isbn:9514274938

Henneron, L., Bernard, L., Hedde, M., Pelosi, C., Villenave C., Chenu, C., Bertrand, M., Girardin, C. \& Blanchart, E. 2015. Fourteen years of evidence for positive effects of conservation agriculture and organic farming on soil life. Agronomy for Sustainable Development 35: 169-181. https://doi.org/10.1007/s13593-014-0215-8

Herrero, M., Havlík, P., Valin, H., Notenbaert, A., Rufino, M.C., Thornton, P.K., Blümmel, M., Weiss, F., Grace, D. \& Obersteiner, M. 2013. Biomass use, production, feed efficiencies, and greenhouse gas emissions from global livestock systems. PNAS 110: 2088820893. https://doi.org/10.1073/pnas.1308149110

Herzon, I., Ekroos, J., Rintala, J., Tiainen, J., Seimola, T. \& Vepsäläinen, V. 2011. Importance of set-aside for breeding birds of open farmland in Finland. Agriculture, Ecosystems and Environment 143: 3-7. https://doi.org/10.1016/j.agee.2011.05.006

Hokkanen, H. 1979. Reserved fields, their use and management in Central Finland in 1974. Journal of the Scientific Agricultural Society of Finland 51: 25-39. (in Finnish). https://doi.org/10.23986/afsci.72016

Hokkanen, H. \& Raatikainen, M. 1977a. Yield, vegetation and succession in reserved fields in Central Finland. Journal of the Scientific Agricultural Society of Finland 49: 221-238. https://doi.org/10.23986/afsci.71939

Hokkanen, H. \& Raatikainen, M. 1977b. Faunal communities of the field stratum and their succession in reserved fields. Journal of the Scientific Agricultural Society of Finland 49: 390-405. https://doi.org/10.23986/afsci.71953

Hokkanen, H.M.T., Menzler-Hokkanen, I. \& Keva, M. 2017. Long-term yield trends of insect-pollinated crops vary regionally and are linked to neonicotinoid use, landscape complexity, and availability of pollinators. Arthropod-Plant Interactions 11: 449-461. https://doi.org/10.1007/s11829-017-9527-3

Hokkanen, T.J., Gruzdeva, L., Matveeva, E., Luotonen, H. \& Virkajärvi, P. 2006a. Maaperän ja kasvillisuuden ravinteet Tohmajärven laidunkokeessa vuosina 1994-2004. In: Huuskonen, A. (ed.). LUMOLAIDUN: Maisemalaiduntaminen luonnon monimuotoisuuden lisääjänä - tasapaino monimuotoisuuden ja tuottavuuden välillä. Maa- ja elintarviketalous 79: 212-244. (in Finnish). 
Hokkanen, T.J., Hokkanen, H. \& Virkajärvi, P. 2006b. Laidunnuksen vaikutus maakiitäjäislajistoon Tohmajärven laidunkokeessa. In: Huuskonen, A. (ed.). LUMOLAIDUN: Maisemalaiduntaminen luonnon monimuotoisuuden lisääjänä - tasapaino monimuotoisuuden ja tuottavuuden välillä. Maa- ja elintarviketalous 79: 245-260. (in Finnish). http://urn.fi/URN:ISBN:952-487-031-2

Hokkanen, T.J., Tuupanen, R., Maksimov, A., Potemkin, A., Maksimova, T. \& Virkajärvi, P. 2006c. Kasvillisuus Tohmajärven metsäja niittylaitumilla 1994-2004. In: Huuskonen, A. (ed.). LUMOLAIDUN: Maisemalaiduntaminen luonnon monimuotoisuuden lisääjänä - tasapaino monimuotoisuuden ja tuottavuuden välillä. Maa- ja elintarviketalous 79: 183-211. (in Finnish). http://urn.fi/URN:ISBN:952-487-031-2

Huhta, A.-P. 2001. Restorative mowing on semi-natural grasslands: community-level changes and species-level responses. Ph. D. thesis, Acta Universitatis Ouluensis, Series A, Scientiae rerum naturalium 365 University of Oulu. 40 p. http://jultika.oulu.fi/files/isbn9514259947.pdf

Huhta, V. \& Raatikainen, M. 1974. Spider communities of leys and winter cereal fields in Finland. Annales Zoologici Fennici 11: 97-104.

Huitu, O., Jokinen, I., Korpimäki, E., Koskela, E. \& Mappes, T. 2007. Phase dependence in winter physiological condition of cyclic voles. Oikos 116: 565-577. https://doi.org/10.1111/j.0030-1299.2007.15488.x

Huitu, O., Koivula, M., Korpimäki, E., Klemola, T. \& Norrdahl, K. 2003. Winter food supply limits growth of northern vole populations in the absence of predation. Ecology 84: 2108-2118. https://doi.org/10.1890/02-0040

Huusela-Veistola, E. 1998. Effects of perennial grass strips on spiders (Araneae) in cereal fields and impact on pesticide side effect. Journal of Applied Entomology 122: 575-583. https://doi.org/10.1111/j.1439-0418.1998.tb01548.x

Huusela-Veistola, E. 2000. Effects of pesticide use and perennial grass strips on arthropod fauna in a northern field ecosystem. Ph.D. thesis, Annales Universitatis Turkuensis Ser. All, Tom. 130. 95 p.

Huusela-Veistola, E. \& Hyvönen, T. 2006. Rotational fallows in support of functional biodiversity. In: Rossing, W.A.H., Eggenschwiler, L. \& Poehling, H.-M. (eds.). Landscape management for functional biodiversity. IOBC wprs Bulletin 29: 61-64.

Huusela-Veistola, E. \& Vasarainen, A. 2000. Plant succession in perennial grass strips and effects on the diversity of leafhoppers (Homoptera, Auchenorrhyncha). Agriculture, Ecosystems and Environment 80: 101-112. https://doi.org/10.1016/S0167-8809(00)00143-2

Hyvönen, T. \& Huusela-Veistola, E. 2011. Impact of seed mixture and mowing on food abundance for farmland birds in set-asides. Agriculture, Ecosystems and Environment 143: 20-27. https://doi.org/10.1016/j.agee.2011.04.008

Hyvönen, T. \& Jalli, H. 2011. Alien species in the Finnish weed flora. Agricultural and Food Science 20: 86-95. https://doi.org/10.2137/145960611795163079

Hyvönen, T., Ketoja, E., Salonen, J., Jalli, H. \& Tiainen, J. 2003. Weed species diversity and community composition in organic and conventional cropping of spring cereals. Agriculture, Ecosystems \& Environment 97: 131-149.

https://doi.org/10.1016/S0167-8809(03)00117-8

Hyytinen, T. 1974. Winter nutrition of the brown hare (Lepus europaeus Pallas) in western Central Finland. Suomen Riista 25: 42-49. (in Finnish).

IPCC 2014. Climate change 2014. Synthesis report. Core Writing Team, Pachauri, R.K. \& Meyer, L.A. (eds.). Contribution of working groups I, II and III to the fifth assessment report of the Intergovernmental Panel on Climate Change. IPCC, Geneva, Switzerland. 151 p.

Jantunen, J. 2003a. Semi-natural grasslands and their vegetation under different agricultural practices. Ph.D. Dissertations in Biology no 17. University of Joensuu. 96 p.

Jantunen, J. 2003b. Vegetation changes in a semi-natural grassland during mowing and grazing periods. Annales Botanici Fennici 40: 255-263. http://www.sekj.org/PDF/anbf40/anbf40-255.pdf

Jantunen, J. \& Saarinen, K. 2002. Vegetation of the uncultivated arable land under different management history in Finnish and Russian Karelia. Agriculture, Ecosystems and Environment 92: 225-233. https://doi.org/10.1016/S0167-8809(01)00289-4

Jantunen, J. \& Saarinen, K. 2003. A comparison of the vegetation in semi-natural grasslands under different agricultural practices in Finnish and Russian Karelia. Nordic Journal of Botany 22: 617-626. https://doi.org/10.1111/j.1756-1051.2002.tb01918.x

Jantunen, J., Saarinen, K. \& Marttila, O. 2003. A comparison of vegetation in grazed, formerly grazed and ungrazed valuable seminatural grasslands in SE Finland. Memoranda Societatis pro Fauna et Flora Fennica 78: 55-61.

Jauni, M. 2012. Plant invasion in boreal agricultural habitats - the effect of environmental conditions, species traits and the impact on native diversity. Ph.D. thesis. Department of Agricultural Sciences Publications 12. University of Helsinki. https://helda.helsinki. fi/handle/10138/35802

Jauni, M., Helenius, J. \& Hyvönen, T. 2012. Changes in the invasion level, and impact of alien plants in Finnish semi-natural agricultural habitats. Agricultural and Food Science 21: 100-117. https://doi.org/10.23986/afsci.5136

Jauni, M. \& Hyvönen. T. 2010. Invasion level of alien plants in seminatural agricultural habitats in boreal region. Agriculture, Ecosystems and Environment 138: 109-115. https://doi.org/10.1016/j.agee.2010.04.007

Jauni, M. \& Hyvönen, T. 2012a. Interactions between alien plant species traits and habitat characteristics in agricultural landscapes in Finland. Biological Invasions 14: 47-63. https://doi.org/10.1007/s10530-011-0058-z

Jauni, M. \& Hyvönen, T. 2012b. Positive diversity-invasibility relationships across multiple scales in Finnish agricultural habitats. Biological Invasions 14: 1379-1391. https://doi.org/10.1007/s10530-011-0163-z

Järvenranta, K., Virkajärvi, P. \& Heinonen-Tanski, H. 2014. The flows and balances of P, K, Ca and Mg on intensively managed boreal high input grass and low input grass-clover pastures. Agricultural and Food Science 23: 106-117.

https://doi.org/10.23986/afsci.41195 


\section{AGRICULTURAL AND FOOD SCIENCE}

J. Tiainen et al. (2020) 29: 68-97

Johansen, L., Westin, A., Wehn, S., luga, A., Ivascu, C.M., Kallioniemi, E. \& Lennartsson, T. 2019. Traditional semi-natural grassland management with heterogeneous mowing times enhances flower resources for pollinators in agricultural landscapes. Global Ecology and Conservation 18: e00619. https://doi.org/10.1016/j.gecco.2019.e00619

Jonason, D., Ekroos, J., Öckinger, E., Helenius, J., Kuussaari, M., Tiainen, J., Smith, H. \& Lindborg, R. 2017. Weak functional response to agricultural landscape homogenisation among plants, butterflies and birds. Ecography 40: 1221-1230. https://doi.org/10.1111/ecog.02268

Jukola-Sulonen, E.-L. 1983. Vegetation succession of abandoned hay fields in Central Finland. A quantitative approach. Communicationes Instituti Forestalis Fenniae 112: 1-85.

Jutila, H. 1999a. Vegetation and seed bank of grazed and ungrazed Baltic coastal meadows in SW Finland. Ph.D. thesis. Annales Universitatis Turkuensis Ser. All, Tom. 115: 191 p.

Jutila, H. 1999b. Effects of grazing on the vegetation of shore meadows along the Bothnian Sea, Finland. Plant Ecology 140: 7788. https://doi.org/10.1023/A:1009744117329

Kaartinen, R., Hardwick, B. \& Roslin, T. 2013. Using citizen scientists to measure an ecosystem service nationwide. Ecology 94 : 2645-2652. https://doi.org/10.1890/12-1165.1

Kajak, A. 1960. Changes in the abundance of spiders in several meadows. Ekologia Polska (A) 8: 199-228. (in Polish).

Kajan, T. \& Nousiainen, J. 2006. Rikkakasvitorjunnan vaikutus säilörehunurmen rehuyksikkösatoon. BSc (Agr.) thesis. Savonia University of Applied Sciences. 63 p. (in Finnish).

Karhula, T. \& Niemi, J.K. 2018. Livestock production. In: Niemi, J. \& Väre, M. (eds.). Agriculture and food sector in Finland 2018. Natural resources and bioeconomy studies 35/2018. Natural Resources Institute Finland, Helsinki. p. $37-42$. http://urn.fi/URN:ISBN:978-952-326-602-5

Kinnunen, H., Järveläinen, K., Pakkala, T. \& Tiainen, J. 1996. The effect of isolation on the occurrence of farmland carabids in a fragmented landscape. Annales Zoologici Fennici 33: 165-171. http://www.sekj.org/PDF/anzf33/anzf33-165p.pdf

Kinnunen, H. \& Tiainen, J. 1999. Carabid distribution in a farmland mosaic - the effect of patch type and location. Annales Zoologici Fennici 36: 149-158. http://www.sekj.org/PDF/anzf36/anzf36-149p.pdf

Kinnunen, H., Tiainen, J. \& Tukia, H. 2001. Farmland carabid beetle communities at multiple levels of spatial scale. Ecography 24: 189-197. https://doi.org/10.1034/j.1600-0587.2001.240209.x

Komonen, A. \& Kataja-aho, S. 2017. Springtails (Collembola) in meadows, pastures and road verges in Central Finland. Entomologica Fennica 28: 157-163. https://doi.org/10.33338/ef.84683

Koskela, H. 1972. Habitat selection of dung-inhabiting Staphylinids (Coleoptera) in relation to age of the dung. Annales Zoologici Fennici 9: 156-171.

Koskela, H. \& Hanski, I. 1977. Structure and succession in a beetle community inhabiting cow dung. Annales Zoologici Fennici 14: 204-223.

Kosonen, M. 1969. Primary production, composition and seasonal growth rhythm of some dry meadow communities on the south coast of Finland. Commentationes Biologicae Societatis Scientiarum Fennica 31: 1-23.

Kuitunen, K., Saarinen, K., Jantunen, J. \& Saarnio, S. 2003. A comparsion of farmland avifauna between Finnish and Russian Karelia. Ornis Fennica 80: 172-181.

Kurtto, A. 1993. Niityt ja kedot. In: Pälkäs, O. (ed.). Keto-opas. Suomen luonnonsuojeluliitto, Helsinki. p. 5-13. (in Finnish)

Kuusela, E. 2004. Grazing management for Nordic organic farming. Ph.D. Dissertations in Biology no 32, University of Joensuu. 154 p. https://epublications.uef.fi/pub/urn_isbn_952-458-587-1/urn_isbn_952-458-587-1.pdf

Kuusela, E. \& Hytti, N. 2001. Effect of dicot weed of nutritive value of pasture herbage in organic farming. In: Isselstein, J., Spatz, G. \& Hofmann, M. (eds.). Organic farming. Proceedings of International Occasional Symposium of the European Grassland Federation. Witzenhausen, Germany, 10-12 July, 2001. Grassland Science in Europe 6: 110-112.

Kykkänen, S., Virkajärvi, P., Saarijärvi, K. \& Kurppa, S. 2014. Nurmiviljelyn ympäristövaikutusten kokonaisvaltainen mittaaminen. In: Kuisma, R., Schulman, N., Kymäläinen, H.-R. \& Alakukku, L. (eds.). Maataloustieteen Päivät 2014, 8.-9.1.2014, Viikki, Helsinki, esitelmä- ja posteritiivistelmät. Suomen Maataloustieteellisen Seuran Tiedote 31. (in Finnish).

Lagerlöf, J., Goffre, B. \& Vincent, C. 2002. The importance of field boundaries for earthworms (Lumbricidae) in the Swedish agricultural landscape. Agriculture, Ecosystems and Environment 89: 91-103. https://doi.org/10.1016/S0167-8809(01)00321-8

Landis, D.A. 2017. Designing agricultural landscapes for biodiversity-based ecosystem services. Basic and Applied Ecology 18: 1-12. https://doi.org/10.1016/j.baae.2016.07.005

Lehtomaa, L., Ahonen, I., Hakamäki, H., Häggblom, M., Jantunen, J., Jutila, H., Järvinen, C., Kemppainen, R., Kondelin, H., Laitinen, T., Lipponen, M., Mussaari, M., Pessa, J., Raatikainen, K.J., Raatikainen, K., Tuominen, S., Vainio, M., Vieno, M. \& Vuomajoki, M. 2018. Perinnebiotoopit. In: Kontula, T. \& Raunio, A. (eds.). Threatened habitat types in Finland 2018. Red list of habitats. Part II: Description of habitat types. The Finnish Environment 5/2018. Finnish Environment Institute and Ministry of Environment. 925 p. http://urn.fi/URN:ISBN:978-952-11-4819-4. (in Finnish).

Leip, A., Billen, G., Garnier, J., Grizzetti, B., Lassaletta, L., Reis, S., Simpson, D., Sutton, M.A., de Vries, W., Weiss, F. \& Westhoek, H. 2015. Impacts of European livestock production: nitrogen, sulphur, phosphorus and greenhouse gas emissions, land use, water eutrophication and biodiversity. Environmental Research Letters 10: 115004. https://doi.org/10.1088/1748-9326/10/11/115004

Ma, M. 2005. Species richness vs. Evenness: independent relationships and different responses to edaphic factors. Oikos 111 : 192-198. https://doi.org/10.1111/j.0030-1299.2005.13049.x 
Ma, M. 2006. Plant species diversity of buffer zones in agricultural landscapes: in search of determinants from the local to regional scale. Ph.D. thesis. Department of Applied Biology. Publication no. 27. University of Helsinki. 41 p. + appendices. http://urn.fi/URN:ISBN:952-10-3601-X

Mäkeläinen, S., Harlio, A., Heikkinen, R.K., Herzon, I., Kuussaari, M., Lepikkö, K., Maier, A., Seimola, T., Tiainen, J. \& Arponen, A. 2019. Coincidence of High Nature Value farmlands with bird and butterfly diversity. Agriculture, Ecosystems and Environment 269: 224-233. https://doi.org/10.1016/j.agee.2018.09.030

Maljanen, M.E., Virkajärvi, P. \& Martikainen, P.J. 2012. Dairy cow excreta patches change the boreal grass swards from sink to source of methane. Agricultural and Food Science 21: 91-99. https://doi.org/10.23986/afsci.5016

Malmberg., S., Mannerkoski, I., Martikainen, P., Clayhills, T., Helve, E., Hyvärinen, E., Karjalainen, E., Mattila, J., Muona, J. \& Rassi, P. 2019. Kovakuoriaiset. Beetles. Coleoptera. In: Hyvärinen, E., Juslén, A., Kemppainen, E., Uddström, A. \& Liukko, U.-M. (eds.). The 2019 Red List of Finnish species. Ministry of the Environment \& Finnish Environment Institute. p. 391-425. (in Finnish). http://hdl.handle.net/10138/299501

Mangels, J., Fiedler, K., Schneider, F.D. \& Blüthgen, N. 2017. Diversity and trait composition of moths respond to land-use intensity in grasslands: Generalists replace specialists. Biological Conservation 26: 3385-3405. https://doi.org/10.1007/s10531-017-1411-z

Manoharan, L., Kushwaha, S.K., Ahrén, D. \& Hedlund, K. 2017. Agricultural land use determines functional genetic diversity of soil microbial communities. Soil Biology and Biochemistry 115: 423-432. https://doi.org/10.1016/j.soilbio.2017.09.011

Marja, R., Herzon, I., Rintala, J., Tiainen, J. \& Seimola, T. 2013. Type of agricultural drainage modifies the value of fields for farmland birds. Agriculture, Ecosystems and Environment 165: 184-189. https://doi.org/10.1016/j.agee.2012.11.008

Mehtälä, J., Pakkala, T. \& Halenius, P. 1985. The birds of two large field areas in Vantaa, southern Finland, in 1973 and 1984. Lintumies 20: 182-186. (in Finnish).

Mela, T. 1969. The effects of N-dimethylaminosuccinamid acid (B-995) on the seed cultivation characteristics of late-flowering red clover. Acta Agricultrurae Fenniae 115: 1-114.

Metera, E., Sakowski, T., Słoniewski, K. \& Romanowicz, B. 2010. Grazing as a tool to maintain biodiversity of grassland - a review. Animal Science Papers and Reports 28: 315-334.

Mikola, J., Setälä, H., Virkajärvi, P., Saarijärvi, K., Ilmarinen, I., Voigt, W. \& Vestberg, M. 2009. Defoliation and patchy nutrient return drive grazing effects on plant and soil properties in a dairy cow pasture. Ecological Monographs 79: $221-244$. https://doi.org/10.1890/08-1846.1

Mkenda, P.A., Ndakidemi, P.A., Mbega, E., Stevenson, P.C., Arnold, S.E.J., Gurr, G.M. \& Belmain, S.R. 2019. Multiple ecosystem services from field margin vegetation for ecological sustainability in agriculture: scientific evidence and knowledge gaps. PeerJ 7:e8091. https://doi.org/10.7717/peerj.8091

MMM 2015. Maa- ja metsätalousministeriön tilusjärjestelystrategia 2015-2020. Maa- ja metsätalousministeriön julkaisuja 1/2015. 14 p. (in Finnish). http://urn.fi/URN:ISBN:978-952-453-875-6

Mukula, J., Raatikainen, M., Lallukka, R. \& Raatikainen, T. 1969. Composition of weed flora in spring cereal fields in Finland. Annales Agriculturae Fenniae 8: 59-110. http://urn.fi/URN:NBN:fi-fe2014102745945

Myllymäki, A. 1959. Bedeutung und Ursachen der Mäusefrassschäden in Finnland. Publications Finnish State Agricultural Research Board 178: 75-99.

Myllymäki, A. 1975. Outbreaks and damage by field rodents and other harmful small mammals in Finland. Ecological Bulletins 19: 17-36.

Myllymäki, A. 1977. Interactions between the field vole Microtus agrestis and its microtine competitors in Central-Scandinavian populations. Oikos 29: 570-580. https://doi.org/10.2307/3543595

Natural Resources Institute Finland 2019a. Milk and milk products statistics. Production of dairy milk annually. http://statdb.luke.fi/PXWeb/pxweb/en/LUKE (visited 17.1.2020)

Natural Resources Institute Finland 2019b. Number of Livestock. Number of dairy cows by year, ELY centre, variable and herd size. http://statdb.luke.fi/PXWeb/pxweb/en/LUKE (visited 17.1.2020)

Natural Resources Institute Finland 2019c. Utilized agricultural area. Utilized agricultural area by year, ELY centre, variable and species. http://statdb.luke.fi/PXWeb/pxweb/en/LUKE (visited 17.1.2020)

Niemelä, M. 2009. Biotic interactions and vegetation management on coastal meadows. Ph.D. thesis. Acta Universitatis Ouluensis, Series A, Scientiae Rerum Naturalium 529. University of Oulu. 68 p. http://jultika.oulu.fi/files/isbn9789514291234.pdf

Niemelä, M., Huuskonen, A., Jaakola, S., Joki-Tokola, E. \& Hyvärinen, M. 2008. Coastal meadows as pastures for beef cattle. Agriculture, Ecosystems and Environment 124: 179-186. https://doi.org/10.1016/j.agee.2007.09.009

Niemi, J., Lepistö, L., Mannio, J., Mitikka, S. \& Pietiläinen, O.-P. 2004. Quality and trends of inland waters. In: Eloranta, P. (ed.). Inland and coastal waters of Finland. Palmenia Publishing, University of Helsinki. p. 18-39.

Nieminen, M., Ketoja, E., Mikola, J., Terhivuo, J., Sirén, T. \& Nuutinen, V. 2011. Local land use effects and regional environmental limits on earthworm communities in Finnish arable landscapes. Ecological Applications 21: 3162-3177. https://doi.org/10.1890/10-1801.1

Norrdahl, K., Klemola, T., Korpimäki, E. \& Koivula, M. 2002. Strong seasonality may attenuate trophic cascades: vertebrate predator exclusion in boreal grassland. Oikos 99: 419-430. https://doi.org/10.1034/j.1600-0706.2002.12025.x

Nuutinen, V. \& Haukka, J. 1990. Conventional and organic cropping systems at Suitia VII: Earthworms. Journal of Agricultural Science in Finland 62: 357-367. https://doi.org/10.23986/afsci.72910

Nykänen, A., Jauhiainen, L., Kemppainen, J. \& \& Lindström, K. 2008. Field-scale spatial variation in yields and nitrogen fixation of clover-grass leys and in soil nutrients. Agricultural and Food Science 17: 376-393. https://doi.org/10.2137/145960608787235568 
Nyroos, H., Partanen-Hertell, M., Silvo, K. \& Kleemola, P. 2006. Vesiensuojelun suuntaviivat vuoteen 2015. Taustaselvityksen lähtökohdat ja yhteenveto tuloksista. Suomen ympäristö 55: 68 p. (in Finnish). http://hdl.handle.net/10138/38785

Paatela, J. 1953. On the botanical composition of the tame-hayfields in Finland. Acta Agriculturae Fenniae 79: 1-128. (in Finnish).

Palojärvi, A., Alakukku, L., Martikainen, E., Niemi, M., Vanhala, P., Jörgensen, K. \& Esala, M. 2000. Soil biological, chemical and physical properties in fields under different management systems. In: Elmholt, S., Stenberg, B., Grönlund, A. \& Nuutinen, V. (eds.). Soil stresses, quality and care. Proceedings from NJF seminar 310, Ås, April 10-12, 2000. DIAS Report Plant Production 38: $109-113$.

Palojärvi, A., Alakukku, L., Martikainen, E., Niemi, M., Vanhala, P., Jørgensen, K. \& Esala, M. 2002. Luonnonmukaisen ja tavanomaisen viljelyn vaikutukset maaperään. Maa- ja elintarviketalous 2. 88 p. (in Finnish). http://www.mtt.fi/met/pdf/met2.pdf

Palojärvi, A. \& Nuutinen, V. 2002. The soil quality concept and its importance in the study of Finnish arable soils. Agricultural and Food Science in Finland 11: 329-342. https://doi.org/10.23986/afsci.5737

Peltonen-Sainio, P., Jauhiainen, L., Laurila, H., Sorvali, J., Honkavaara, E., Wittke, S., Karjalainen, M. \& Puttonen, E. 2019. Land use optimization tool for sustainable intensification of high-latitude agricultural systems. Land Use Policy 88: 104104. https://doi.org/10.1016/j.landusepol.2019.104104

Penttilä, A., Slade, E.M., Simojoki, A., Riutta, T., Minkkinen, K. \& Roslin, T. 2013. Quantifying beetle-mediated effects on gas fluxes from dung pats. PLoS ONE 8(8):e71454. https://doi.org/10.1371/journal.pone.0071454

Persson, T. \& Lohm, U. 1977. Energetical significance of the annelids and arthropods in a Swedish grassland soil. Ecological Bulletins 23: 1-207.

Pessa, J., Timonen, S., Sjöholm, J. \& Holmström, H. 2006. Laiduntamalla ja niittämällä hoidettujen Perämeren rantaniittyjen linnusto. In: Huuskonen, A. (ed.). LUMOLAIDUN: Maisemalaiduntaminen luonnon monimuotoisuuden lisääjänä - tasapaino monimuotoisuuden ja tuottavuuden välillä. Maa- ja elintarviketalous 79: 66-109. (in Finnish). http://urn.fi/URN:ISBN:952-487-031-2

Piccini, I., Arnieri, F., Caprio, E., Nervo, B., Pelissetti, S., Palestrini, C., Roslin, T. \& Rolando, A. 2017. Greenhouse gas emissions from dung pats vary with dung beetle species and with assemblage composition. PLoS ONE 12(7): e0178077. https://doi.org/10.1371/journal.pone.0178077

Piccini, I., Nervo, B., Forshage, M., Celi, L., Palestrini, C., Rolando, A. \& Roslin, T. 2018. Dung beetles as drivers of ecosystem multifunctionality: Are response and effect traits interwoven? Science of the Total Environment 616-617: 1440-1448. https://doi.org/10.1016/j.scitotenv.2017.10.171

Piha, M., Lindén, A., Pakkala, T. \& Tiainen, J. 2007a. Linking weather and habitat to population dynamics of a migratory farmland songbird. Annales Zoologici Fennici 44: 20-34. http://www.sekj.org/PDF/anzf44/anzf44-020.pdf

Piha, M., Pakkala, T. \& Tiainen, J. 2003. Habitat preferences of the Skylark Alauda arvensis in southern Finland. Ornis Fennica 80: 97-110

Piha, M., Tiainen, J., Holopainen, J. \& Vepsäläinen, V. 2007b. Effects of land-use and landscape characteristics on avian diversity and abundance in a boreal agricultural landscape with organic and conventional farms. Biological Conservation 140: $50-61$. https://doi.org/10.1016/j.biocon.2007.07.021

Piha, M., Tiainen, J., Seimola, T. \& Vepsäläinen, V. 2007c. Modelling diversity and abundance of Finnish famland birds - landscape characteristics define the diversity and conservation hotspots. In: Piha, M. Spatial and temporal determinants of Finnish farmland bird populations. Ph.D. thesis, University of Helsinki. p. 57-78.

Piippo, S. 2010. Grazing tolerance of biennial meadow plants in relation to resource availability. Ph.D. thesis. Acta Universitatis Ouluensis, Series A, Scientiae Rerum Naturalium 557. University of Oulu. 58 p. http://urn.fi/urn:isbn:9789514262111

Plantureux, S., Bernués, A., Huguenin-Elie, O., Hovstad, K., Isselstein, J., McCracken, D., Therond, O. \& Vackar, D. 2016. Ecosystem service indicators for grasslands in relation to ecoclimatic regions and land use systems. In: Höglind, M., Bakken, A.K., Hovstad, K.A., Kallioniemi, E., Riley, H., Steinhamm, H. \& Østrem, L. (eds.). The multiple roles of grassland in the European bioeconomy. Proceedings of the $26^{\text {th }}$ General Meeting of the European Grassland Federation. Trondheim, Norway, 4-8. Grassland Science in Europe 21: 524-547. https://www.europeangrassland.org/fileadmin/documents/Infos/Printed_Matter/Proceedings/EGF2016.pdf

Plantureux, S., Peeters, A. \& McCracken, D. 2005. Biodiversity in intensive grasslands: effect of management, improvement and challenges. Agronomy Research 3: 153-164. https://agronomy.emu.ee/wp-content/uploads/2005/02/p3203.pdf

Pöyry, J. 2007. Management of semi-natural grasslands for butterfly and moth communities. Ph.D. thesis, University of Helsinki. http://urn.fi/URN:ISBN:978-952-10-4217-1

Pöyry, J., Lindgren, S., Salminen, J. \& Kuussaari, M. 2004. Restoration of butterfly and moth communities in semi-natural grasslands by cattle grazing. Ecological Applications 14: 1656-1670. https://doi.org/10.1890/03-5151

Pöyry, J., Lindgren, S., Salminen, J. \& Kuussaari, M. 2005. Responses of butterfly and moth species to restored cattle grazing in semi-natural grasslands. Biological Conservation 122: 465-478. https://doi.org/10.1016/j.biocon.2004.09.007

Pöyry, J., Luoto, M., Paukkunen, J., Pykälä, J., Raatikainen, K. \& Kuussaari, M. 2006. Different responses of plants and herbivore insects to a gradient of vegetation height: an indicator of the vertebrate grazing intensity and successional age. Oikos 115: 401412. https://doi.org/10.1111/j.2006.0030-1299.15126.x

Pöyry, J., Paukkunen, J., Heliölä, J. \& Kuussaari, M. 2009. Relative contributions of local and regional factors to species richness and total density of butterflies and moths in semi-natural grasslands. Oecologia 160: 577-587. https://doi.org/10.1007/s00442-009-1328-7

Pulleman, M., Creamer, R., Hamer, U., Helder, J., Pelosi, C., Peres, G. \& Rutgers, M. 2012. Soil biodiversity, biological indicators and soil ecosystem services - an overview of European approaches. Current Opinion in Environmental Sustainability 4: 529-538. https://doi.org/10.1016/j.cosust.2012.10.009

Pullinen, S. 1986. The vegetation succession on abandoned fields. Memoranda Societatis pro Fauna et Flora Fennica $62: 83-87$ (in Finnish). 


\section{AGRICULTURAL AND FOOD SCIENCE}

J. Tiainen et al. (2020) 29: 68-97

Puurunen, T. \& Virkajärvi, P. 2005. Nurmitilan kasvinsuojelu: opas nurmitilan kasvinsuojeluun Pohjois-Savossa. Pro Agria, MTT \& Pohjois-Savon TE-keskus. 29 p. (in Finnish).

Puustinen, M., Tattari, S., Väisänen, S., Virkajärvi, P., Räty, M., Järvenranta, K., Koskiaho, J., Röman, E., Sammalkorpi, I., Uusitalo, R., Lemola, R., Uusi-Kämppä, J., Lepistö, A., Hjerppe, T., Riihimäki, J. \& Ruuhijärvi, J. 2019. Nutrient recycling in primary production and its effects on state of surface waters, KiertoVesi. KiertoVesi-hankkeen loppuraportti. Suomen ympäristökeskuksen raportteja 22/2019. 142 p. (in Finnish). http://hdl.handle.net/10138/304956

Pykälä, J. 2001. Maintaining biodiversity through traditional animal husbandry. Suomen ympäristö $495: 205$ p. (in Finnish). http://hdl.handle.net/10138/228396

Pykälä, J. 2003. Effects of restoration with cattle grazing on plant species composition and richness of semi-natural grasslands. Biodiversity and Conservation 12: 2211-2226. https://doi.org/10.1023/A:1024558617080

Pykälä, J. 2004. Cattle grazing increases plant species richness of most species trait groups in mesic semi-natural grasslands. Plant Ecology 175: 25-33. https://doi.org/10.1007/s11258-005-0015-y

Pykälä, J. 2005. Plant species responses to cattle grazing in mesic semi-natural grassland. Agriculture, Ecosystems and Environment 108: 109-117. https://doi.org/10.1016/j.agee.2005.01.012

Pykälä, J. 2007. Maintaining plant species richness by cattle grazing: mesic semi-natural grasslands as focal habitats. Ph.D. thesis. Publications in Botany from the University of Helsinki N:o 36. http://urn.fi/URN:ISBN:978-952-10-4205-8

Pykälä, J., Luoto, M., Heikkinen, R.K. \& Kontula, T. 2005. Plant species richness and persistence of rare plants in abandoned seminatural grasslands in northern Europe. Basic and Applied Ecology 6: 25-33. https://doi.org/10.1016/j.baae.2004.10.002

Quijas, S. \& Balvanera, P. 2013. Biodiversity and ecosystem services. In: Levin, S.A. (ed.). Encyclopedia of Biodiversity, Volume 1: 341-356. Second edition. Academic Press, Waltham, MA. https://doi.org/10.1016/B978-0-12-384719-5.00349-X

Raatikainen, K.M., Heikkinen, R.K. \& Luoto, M. 2009. Relative importance of habitat area, connectivity, management and local factors for vascular plants: spring ephemerals in boreal semi-natural grasslands. Biodiversity and Conservation 18: $1067-1085$. https://doi.org/10.1007/s10531-008-9462-9

Raatikainen, K.M., Heikkinen, R.K. \& Pykälä, J. 2007. Impacts of local and regional factors on vegetation of boreal semi-natural grasslands. Plant Ecology 189: 155-173. https://doi.org/10.1007/s11258-006-9172-x

Raatikainen, M. \& Huhta, V. 1968. On the spider fauna of Finnish oat fields. Annales Zoologici Fennici 5: $254-261$.

Raatikainen, M. \& livarinen, R. 1986. Beetle fauna of field layer in hay meadows in Finland. Acta Entomologica Fennica 46:1-42.

Raatikainen, M. \& Raatikainen, T. 1975. Yield, composition and dynamics of flora in grasslands for hay in Finland. Annales Agriculturae Fenniae 14: 57-191. (in Finnish). http://urn.fi/URN:NBN:fi-fe2014102045383

Raatikainen, T. 1986. Changes in the plant biomass in leys in Finland. Memoranda Societatis pro Fauna et Flora 62: 74-78. (in Finnish).

Rainio, M. 1966. Abundance and phenology of some coprophagous beetles in different kinds of dung. Annales Zoologici Fennici 3: 88-98.

Ranta, E. \& Tiainen, M. 1982. Structure in seven bumblebee communities in eastern Finland in relation to resource availability. Holarctic Ecology 5: 48-54. https://doi.org/10.1111/j.1600-0587.1982.tb01016.x

Ranta, E. \& Vepsäläinen, K. 1981. Why are there so many species? Spatio-temporal heterogeneity and northern bumblebee communities. Oikos 36: 28-34. https://doi.org/10.2307/3544375

Räty, M., Virkajärvi, P., Järvenranta, K. \& Hyrkäs, M. 2018. Nurmelle kesällä ja syksyllä sijoittamalla levitetyn lietelannan satovaikutus ja ravinnehuuhtouma. In: Puhakainen, T. \& Hakojärvi, M. (eds.). Maataloustieteen Päivät 2018, 10.-11.1.2018, Helsinki. Esitelmäja posteritiivistelmät. Suomen Maataloustieteellisen Seuran Tiedote 34. https://journal.fi/smst/issue/view/5992

Reichlin, T., Klansek, E. \& Hackländer, K. 2006. Diet selection by hares (Lepus europaeus) in arable land and its implications for habitat management. European Journal of Wildlife Research 52: 109-118. https://doi.org/10.1007/s10344-005-0013-3

Reid, R.S., Bedelian, C. Said, M.Y., Kruska, R.L., Mauricio, R.M., Castel, V., Olson, J. \& Thornton, P.K. 2010. Global livestock impacts on biodiversity. In: Steinfeld, H., Mooney, H.A., Schneider, F. \& Neville, L.E. (eds.). Livestock in a changing landscape. Volume 1. Drivers, consequences, and responses. Island Press, Washington. p. 111-137.

Rintala, J. \& Tiainen, J. 2007. Indexing long-term regional bird population dynamics with nestling ringing data. Annales Zoologici Fennici 44: 115-140. http://www.sekj.org/PDF/anzf44/anzf44-115.pdf

Rintala, J. \& Tiainen, J. 2008. A model incorporating a reduction in carrying capacity translates brood size trends into a population decline: the case of the Finnish starlings, 1951-2005. Oikos 117: 47-59. https://doi.org/10.1111/j.2007.0030-1299.16141.x

Roslin, T. 1999. Spatial ecology of dung beetles. Ph.D. thesis, University of Helsinki. http://urn.fi/URN:ISBN:951-45-8696-4

Roslin, T. 2000. Dung beetle movements at two spatial scales. Oikos 91:323-335. https://doi.org/10.1034/j.1600-0706.2000.910213.x

Roslin, T. 2001. Large-scale spatial ecology of dung beetles. Ecography 24: 511-524.

https://doi.org/10.1034/j.1600-0587.2001.d01-207.x

Roslin, T., Forshage, M., Ødegaard, F., Ekblad, C. \& Liljeberg, G. 2014. Nordens dygnbaggar. Hyönteistarvike Tibiale Oy, Helsingfors. 356 p. (in Swedish).

Roslin, T. \& Heliövaara, K. 2007. Suomen lantakuoriaiset. Opas santiaisista lantiaisiin. Helsinki University Press, Helsinki. 244 p. (in Finnish).

Roslin, T. \& Koivunen, A. 2001. Distribution and abundance of dung beetles in fragmented landscapes. Oecologia 127: 69-77. https://doi.org/10.1007/s004420000565 
Saarijärvi, K. 2008. Nitrogen cycling on intensively managed boreal dairy pastures. Ph.D. thesis. Agrifood Research Reports 134. MTT Agrifood Research Finland, Jokioinen, Finland. 71 p. http://urn.fi/URN:ISBN:978-952-487-204-1

Saarinen, K. 2002a. Butterfly communities in relation to changes in the management of agricultural environments. Ph.D. Dissertations in Biology no 13, University of Joensuu. 94 p.

Saarinen, K. 2002b. A comparison of butterfly communities along field margins under traditional and intensive management in SE Finland. Agriculture, Ecosystems and Environment 90: 59-65. https://doi.org/10.1016/S0167-8809(01)00168-2

Saarinen, K. \& Jantunen, J. 2002. A comparison of the butterfly fauna of agricultural habitats under different management history in Finnish and Russian Karelia. Annales Zoologici Fennici 39: 173-181. http://www.sekj.org/PDF/anzf39/anzf39-173p.pdf

Saarinen, K. \& Jantunen, J. 2005. Grassland butterfly fauna under traditional animal husbandry: contrasts in diversity in mown meadows and grazed pastures. Biodiversity and Conservation 14: 3201-3213. https://doi.org/10.1007/s10531-004-0387-7

Schöps, R., Goldmann, K., Herz, K., Lentendu, G., Schöning, I., Bruelheide, H., Wubet, T. \& Buscot, F. 2018. Land-use intensity rather than plant functional identity shapes bacterial and fungal rhizosphere communities. Frontiers in Microbiology 9:2711. https://doi.org/10.3389/fmicb.2018.02711

Simons, N.K., Gossner, M.M., Lewinsohn, T.M., Lange, M., Türke, M. \& Weisser, W.W. 2015. Effects of land-use intensity on arthropod species abundance distributions in grasslands. Journal of Animal Ecology 84: 143-154. https://doi.org/10.1111/1365-2656.12278

Slade, E.M., Kirwan, L., Bell, T. Philipson, C.D., Lewis, O.T. \& Roslin, T. 2017. The importance of species identity and interactions for multifunctionality depends on how ecosystem functions are valued. Ecology 98: 2626-2639. https://doi.org/10.1002/ecy.1954

Slade, E.M., Riutta, T., Roslin, T. \& Tuomisto, H.L. 2016a. The role of dung beetles in reducing greenhouse gas emissions from cattle farming. Scientific Reports 6: 18140. https://doi.org/10.1038/srep18140

Slade, E.M., Roslin. T., Santalahti, M. \& Bell, T. 2016b. Disentangling the 'brown world' faecal-detritus interaction web: dung beetle effects on soil microbial properties. Oikos 125: 629-635. https://doi.org/10.1111/oik.02640

Solonen, T., Tiainen, J., Korpimäki, E. \& Saurola, P. 1991. Dynamics of the Finnish Starling Sturnus vulgaris populations in recent decades. Ornis Fennica 68: 158-169.

Soveri, J. 1940. Die Vogelfauna von Lammi, ihre regionale Verbreitung und Abhängigkeit von den ökologischen Faktoren. Acta Zoologica Fennica 27: 1-176.

Spatz, G. \& Baumgartner, A. 1990. Zur Bewertung der Grünlandkräuter als Futterpflanzen. Das Wirtschaftseigene Futter 36: 79-91.

Takala, T., Tahvanainen, T. \& Kouki, J. 2014. Grazing promotes bryophyte species richness in semi-natural grasslands. Annales Botanici Fennici 51: 148-160. https://doi.org/10.5735/085.053.0102

Tarmi, S. 2011. Plant communities of field margins - the effects of management and environmental factors on species composition and diversity. Ph.D. thesis. Department of Agricultural Sciences Publications 7. University of Helsinki. http://urn.fi/URN:ISBN:978-952-10-4314-7

Tarmi, S., Helenius, J. \& Hyvönen, T. 2009. Importance of edaphic, spatial and management factors for plant communities of field boundaries. Agriculture, Ecosystems and Environment 131: 201-206. https://doi.org/10.1016/j.agee.2009.01.016

Tarmi, S., Helenius, J. \& Hyvönen, T. 2011. The potential of cutting regimes to control problem weeds and enhance species diversity in an arable field margin buffer strip. Weed Research 51: 641-649. https://doi.org/10.1111/j.1365-3180.2011.00888.x

Tarmi, S. \& Hyvönen, T. 2012. Plant species diversity and composition of plant communities in buffer zones with variable management regimes. Sustainable Agriculture Research 1: 152-161. https://doi.org/10.5539/sar.v1n2p152

Tarmi, S., Tuuri, H. \& Helenius, J. 2002. Plant communities of field boundaries in Finnish farmland. Agricultural and Food Science in Finland 11: 121-135. https://doi.org/10.23986/afsci.5717

Tattari, S., Koskiaho, J., Kosunen, M., Lepistö, A., Linjama, J. \& Puustinen, M. 2017. Nutrient loads from agricultural and forested areas in Finland from 1981 up to 2000 - can the efficiency of undertaken water protection measures seen? Environmental Monitoring and Assessment 189: 95. https://doi.org/10.1007/s10661-017-5791-z

Teräs, I. 1976a. Bumblebees, Bombus Latr. (Hymenoptera, Apidae), on red clover in South Savo, Finland. Annales Agriculturae Fenniae 15: 116-127. http://urn.fi/URN:NBN:fi-fe2014102045386

Teräs, I. 1976b. Flower visits of bumblebees, Bombus Latr. (Hymenoptera, Apidae), during one summer. Annales Zoologici Fennici 13: 200-232.

Teräs, I. 1985. Food plants and flower visits of bumblebees (Bombus: Hymenoptera, Apidae) in southern Finland. Acta Zoologica Fennica 179: 1-120.

Tiainen, J. 2004. Maatalousympäristön historia. In: Tiainen, J., Kuussaari, M., Laurila, I.P. \& Toivonen, T. (eds.). Elämää pellossa Suomen maatalousympäristön monimuotoisuus. Edita Publishing, Helsinki. p. 26-40. (in Finnish).

Tiainen, J. \& Pakkala, T. 2001. Birds. In: Pitkänen, M. \& Tiainen, J. (eds.). Biodiversity of argicultural landscapes in Finland. BirdLife Finland Conservation Series 3: 33-50.

Tiainen, J. \& Seimola, T. 2014. Density variation among habitats of south Finnish farmland. Linnut-vuosikirja 2013: 70-77. (in Finnish).

Tiainen, J., Pakkala, T., Piiroinen, J., Vickholm, M. \& Virolainen, E. 1985. Changes in the avifauna of farmland at Lammi, southern Finland during the past 50 years. Lintumies 20: 30-42. (in Finnish).

Tiainen, J., Hanski, I. K., Pakkala, T., Piiroinen, J. \& Yrjölä, R. 1989. Clutch size, nestling growth and nestling mortality of the Starling Sturnus vulgaris in south Finnish agroenvironments. Ornis Fennica 66: 41-48.

Tiainen, J., Pakkala, T., Piiroinen, J., Rintala, J. \& Sirkiä, J. 2001. Long-term population development of Skylarks Alauda arvensis in Finland. In: Donald, P.F. \& Vickery, J.A. (eds.). The ecology and conservation of skylarks Alauda arvensis. Proceedings of a conference held at the University of Southampton, 28-29 March, 1999. Royal Society for the Protection of Birds, Sandy, UK. p. 11-24. 
Tiainen, J., Kuussaari, M., Laurila, I.P. \& Toivonen, T. 2004a. Monimuotoisuus tulevaisuuden maatalousympäristössä. In: Tiainen, J., Kuussaari, M., Laurila, I.P. \& Toivonen, T. (eds.). Elämää pellossa - Suomen maatalousympäristön monimuotoisuus. Edita Publishing, Helsinki. p. 350-353. (in Finnish).

Tiainen, J., Piha, M., Piiroinen, J., Rintala, J. \& Vepsäläinen, V. 2004b. Maatalousympäristön pesimälinnusto. In: Tiainen, J., Kuussaari, M., Laurila, I.P. \& Toivonen, T. (eds.). Elämää pellossa - Suomen maatalousympäristön monimuotoisuus. Edita Publishing, Helsinki. p. 147-163. (in Finnish).

Tiainen, J., Seimola, T., Holmström, H. \& Rintala, J. 2012a. Farmland bird populations in Åland in 2011 with a comparison to 2001 and continental Finland. Linnut-vuosikirja 2011: 48-57. (in Finnish).

Tiainen, J., Seimola, T., Rintala, J. \& Holmström, H. 2012b. Changes in farmland bird populations in Finland in 2001-2011. Linnutvuosikirja 2011: 38-47. (in Finnish).

Tiainen, J., Seimola, T. \& Rintala, J. 2014. Maatalousympäristön pesimälinnusto. In: Aakkula, J. \& Leppänen, J. (eds.). Maatalouden ympäristötuen vaikuttavuuden seurantatutkimus (MYTVAS 3) - loppuraportti. Maa- ja metsätalousministeriön julkaisuja 3/2014: 106-132. (in Finnish).

Tischler, W. 1958. Synökologische Untersuchungen an der Fauna der Felder und Feldgehölze. (Ein Beitrag zur Ökologie der Kulturlandschaft.) Zeitschrift der Morphologie und Ökologie der Tiere 47: 54-114. https://doi.org/10.1007/BF00407187

Toivonen, M., Herzon, I. \& Kuussaari, M. 2015. Differing effects of fallow type and landscape structure on the occurrence of plants, pollinators and birds on environmental fallows in Finland. Biological Conservation 181: 36-43. https://doi.org/10.1016/j.biocon.2014.10.034

Toivonen, M., Herzon, I. \& Kuussaari, M. 2016. Community composition of butterflies and bumblebees in fallows: niche breadth and dispersal capacity modify responses to fallow type and landscape. Journal of Insect Conservation $20: 23-34$. https://doi.org/10.1007/s10841-015-9836-8

Toivonen, M., Huusela-Veistola, E. \& Herzon, I. 2018. Perennial fallow strips support biological pest control in spring cereal in Northern Europe. Biological Control 121: 109-118. https://doi.org/10.1016/j.biocontrol.2018.02.015

Törmälä, T. 1979. Numbers and biomass of soil invertebrates in a reserved field in central Finland. Journal of the Scientific Agricultural Society of Finland 51: 172-187. https://doi.org/10.23986/afsci.71997

Törmälä, T. 1980. The bird community of reserved fields in central Finland. Ornis Fennica 57: 161-166.

Törmälä, T. 1982a. Structure and dynamics of reserved field ecosystem in central Finland. Biological Research Reports 8: 1-58. University of Jyväskylä.

Törmälä, T. 1982b. Evaluation of five sampling methods of field layer arthropod, especially the leafhopper community, in grassland. Annales Entomologici Fennici 48: 1-16.

Törmälä, T. 1986. Animal communities in abandoned fields. Memoranda Societatis pro Fauna et Flora Fennica 62: 103-106. (in Finnish).

Törmälä, T. \& Raatikainen, M. 1976. Primary production and seasonal dynamics of the flora and fauna of the field stratum in a reserved field in Middle Finland. Journal of the Scientific Agricultural Society of Finland 48: 363-385. https://doi.org/10.23986/afsci.71926

Tscharntke, T., Karp, D.S., Chaplin-Kramer, R., Batáry, P., DeClerk, F., Gratton, C., Hunt, L., Ives, A., Jonsson, M., Larsen, A., Martin, E.A., Martínez-Salinas, A., Meehan, T.D., O’Rourke, M., Poveda, K., Rosenheim, J.A., Rusch, A., Schellhorn, N., Wanger, T., Wratten, S. \& Zhang, W. 2016. When natural habitat fails to enhance biological pest control - five hypotheses. Conservation Biology 204: 449-458. https://doi.org/10.1016/j.biocon.2016.10.001

Tscharntke, T., Klein, A.M., Kruess, A., Steffan-Dewenter, I. \& Thies, C. 2005. Landscape perspectives on agricultural intensification and biodiversity-ecosystem service management. Ecology Letters 8: 857-874. https://doi.org/10.1111/j.1461-0248.2005.00782.x

Turtola, E. \& Kemppainen, E. 1998. Nitrogen and phosphorus losses in surface runoff and drainage water after application of slurry and mineral fertilizer to perennial grass ley. Agricultural and Food Science in Finland 7: 569-581. https://doi.org/10.23986/afsci.5614

Turunen, J., Muotka, T., Vuori, K.-M., Karjalainen, S.M., Rääpysjärvi, J., Sutela, T. \& Aroviita, J. 2016. Disentangling the responses of boreal stream assemblages to lowstressor levels of diffuse pollution and altered channel morphology. Science of the Total Environment 544: 954-962. https://doi.org/10.1016/j.scitotenv.2015.12.031

Vainio, M., Kekäläinen, H., Alanen, A. \& Pykälä, J. 2001. Traditional rural biotopes in Finland. Final report of the nationwide inventory. Suomen ympäristö 527: 163 p. (in Finnish). http://hdl.handle.net/10138/40675

Valkama, J. \& Currie, D. 1999. Low productivity of Curlews Numenius arquata on farmland in southern Finland: Causes and consequences. Ornis Fennica 76: 65-70.

Valkama, J., Robertson, P. \& Currie, D. 1999. Habitat selection by breeding curlews (Numenius arquata) on farmland: the importance of grassland. Annales Zoologici Fennici 35: 141-148. http://www.sekj.org/PDF/anzf35/anzf35-141p.pdf

Valkama, E., Usva, K., Saarinen, M. \& Uusi-Kämppä, J. 2019. A meta-analysis on nitrogen retention by buffer zones. Journal of Environmental Quality 48: 270-279. https://doi.org/10.2134/jeq2018.03.0120

Valle, O. 1955. Untersuchungen zur Sicherung der Bestäubung von Rotklee. Acta Agralia Fennica 83: $205-220$.

Valle, O., Huokuna, E. \& Puumalainen, T. 1964. The possibilities of seed production of tetraploid red clover in Central Finland. Annales Agriculturae Fenniae 3: 80-94. http://urn.fi/URN:NBN:fi-fe2014102045338

Valle, O., Salminen, M. \& Huokuna, E. 1960. Pollination and seed setting in tetraploid red clover in Finland, II. Acta Agralia Fennica 97: 1-64.

Varis, A.-L., Holopainen, J.K. \& Koponen, M. 1984. Abundance and seasonal occurrence of adult Carabidae (Coleoptera) in cabbage, sugar beet and timothy fields in southern Finland. Zeitschrift für angewandte Entomologie 98: 62-73.

https://doi.org/10.1111/j.1439-0418.1984.tb02686.x 


\section{AGRICULTURAL AND FOOD SCIENCE}

J. Tiainen et al. (2020) 29: 68-97

Varjonen, S. 1991. Kottaraisen (Sturnus vulgaris) pesimäbiologia ja pesäpoikasaikainen ravinnonhankinnan ekologia maatalousympäristössä. M.Sc. thesis, University of Helsinki. 102 p. (in Finnish).

Vepsäläinen, V. 2010. Energy crop cultivations of reed canary grass - An inferior breeding habitat for the skylark, a characteristic farmland bird species. Biomass and Bioenergy 34: 993-998. https://doi.org/10.1016/j.biombioe.2010.02.007

Vepsäläinen, V., Pakkala, T., Piha, M. \& Tiainen, J. 2005. Population crash of the ortolan bunting Emberiza hortulana in an agricultural landscapes of southern Finland. Annales Zoologici Fennici 42: 91-107. http://www.sekj.org/PDF/anzf42/anzf42-091.pdf

Vilbaste, A. 1964. Über die Fauna und Dynamik der Spinnen auf den Auwiesen Estlands. Eesti NSV Teaduste Akad. Toimetised (Biol.) 13: 284-301. (in Estonian).

Vilbaste, A. 1965. Über den Sommeraspekt der Spinnenfauna auf den Kulturwiesen. Eesti NSV Teaduste Akad. Toimetised (Biol.) 14: 329-337. (in Estonian).

Virkajärvi, P., Hokkanen, T.J., Huhta, H. \& Uusi-Kämppä, J. 2006b. Suosituksia emolehmien laidunnukseen metsälaitumilla ja luonnonniityillä. In: Huuskonen, A. (ed.). LUMOLAIDUN: Maisemalaiduntaminen luonnon monimuotoisuuden lisääjänä tasapaino monimuotoisuuden ja tuottavuuden välillä. Maa- ja elintarviketalous 79: 275-285. (in Finnish). http://urn.fi/URN:ISBN:952-487-031-2

Virkajärvi, P., Huhta, H. \& Hokkanen, T.J. 2006a. Luonnonlaitumien rehuarvo ja eläintuotos Tohmajärven laidunkokeessa 19942005. In: Huuskonen, A. (ed.). LUMOLAIDUN: Maisemalaiduntaminen luonnon monimuotoisuuden lisääjänä - tasapaino monimuotoisuuden ja tuottavuuden välillä. Maa- ja elintarviketalous 79: 145-182.http://urn.fi/URN:ISBN:952-487-031-2

Virkajärvi, P. \& Pakarinen, K. 2008. Rehunurmien rikkakasvien torjunta nurmivuosina. In: Jalli, H. (ed.). Kasvinsuojelupäivä, Jokioinen 22.1.2008. Kasvinsuojeluseura. p. 30-35. (in Finnish).

Virkajärvi, P., Pakarinen, K., Hyrkäs, M. \& Suomela, R. 2012. Rikkakasvien torjunta nurmivuosina. In: Nurmesta se kaikki lähtee! Karjatilan kannattava peltoviljely. KARPE-hanke 2009-2012, Maaninka: Maa- ja elintarviketalouden tutkimuskeskus. p. 26-29. (in Finnish).

Virkajärvi, P. \& Punkki, P. 2007. Säilörehunurmien rikkakasvien torjuntakokeiden tuloksia. In: Heikkinen, A.-M., Pakarinen, K., Punkki, P., Rossi, A., Puurunen, T., Sairanen, A. \& Virkajärvi, P. (eds.). Pohjois-Savon nurmiopas: tavoitteena valtakunnan parhaat nurmet. Pelto tuottamaan -hanke. Sonkajärvi, Maaninka: Maito-Savo, MTT Kotieläintuotannon tutkimus. p. 28-30. (in Finnish).

Virkajärvi, P., Rinne, M., Mononen, J., Niskanen, O., Järvenranta, K. \& Sairanen, A. 2015. Dairy production systems in Finland. In: van den Pol-van Dasselaar, A., Aarts, H.F.M., De Vliegher, A., Elgersma, A., Reheul, D., Reijneveld, J.A., Verloop, J. \& Hopkins, A. (eds.). Grassland and forages in high output dairy farming systems. Proceedings of the $18^{\text {th }}$ symposium of the European Grassland Federation, Wageningen, the Netherlands, 15-17 June, 2015. Grassland Science in Europe 20: 51-66. https://www.europeangrassland.org/fileadmin/documents/Infos/Printed_Matter/Proceedings/EGF2015.pdf

Wilman, D. \& Riley, J.A. 1993. Potential nutritive value of a wide range of grassland species. The Journal of Agricultural Science 120: 43-50. https://doi.org/10.1017/S0021859600073573

Wolters, V. 2001. Biodiversity of soil animals and its function. European Journal of Soil Biology 37: $221-227$. https://doi.org/10.1016/S1164-5563(01)01088-3

Wyss, U. \& Vogel, R. 1998. Ensilability of some common grassland herbs. In: Nagy, G. \& Petö, K. (eds.). Ecological aspects of grassland management. Proceedings of $17^{\text {th }}$ EGF general meeting, Debrecen, Hungary, May 18-21, 1998. Grassland Science in Europe 3: 1005-1009.

Yletyinen, S. \& Norrdahl, K. 2008. Habitat use of field voles (Microtus agrestis) in wide and narrow buffer zones. Agriculture, Ecosystems and Environment 123: 194-200. https://doi.org/10.1016/j.agee.2007.06.002

Ylimaunu, J. \& Siira, J. 1985. Changes of breeding bird populations in agricultural areas in Ostrobothnia. Lintumies $20: 43-47$. (in Finnish).

Ylönen, H., Kojola, T. \& Viitala, J. 1988. Changing female spacing behaviour and demography in an enclosed breeding population of Chletrionomus glareolus. Holarctic Ecology 11: 286-292. https://doi.org/10.1111/j.1600-0587.1988.tb00811.x

Yrjölä, R., Tiainen, J. \& Södersved, J. 1986. Changes of the avifauna of farmland in Nummi, southern Finland during the past three decades. Lintumies 21: 19-23. (in Finnish). 